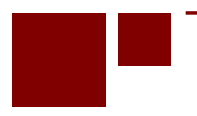

C E N T E R for RETIREMENT RE S E A R C H at BOSTON COLLEGE

\title{
HOW DOES DELAYED RETIREMENT AFFECT MORTALITY AND HEALTH?
}

Alice Zulkarnain and Matthew S. Rutledge

CRR WP 2018-11

October 2018

Center for Retirement Research at Boston College

Hovey House

140 Commonwealth Avenue

Chestnut Hill, MA 02467

Tel: 617-552-1762 Fax: 617-552-0191

http://crr.bc.edu

Alice Zulkarnain and Matthew S. Rutledge are research economists at the Center for Retirement Research at Boston College. The research reported herein was performed pursuant to a grant from the U.S. Social Security Administration (SSA) funded as part of the Retirement Research Consortium. The opinions and conclusions expressed are solely those of the authors and do not represent the opinions or policy of SSA, any agency of the federal government, Boston College, or Statistics Netherlands. Neither the United States Government nor any agency thereof, nor any of their employees, makes any warranty, express or implied, or assumes any legal liability or responsibility for the accuracy, completeness, or usefulness of the contents of this report. Reference herein to any specific commercial product, process or service by trade name, trademark, manufacturer, or otherwise does not necessarily constitute or imply endorsement, recommendation or favoring by the United States Government or any agency thereof.

(C) 2018, Alice Zulkarnain and Matthew S. Rutledge. All rights reserved. Short sections of text, not to exceed two paragraphs, may be quoted without explicit permission provided that full credit, including $($ ) notice, is given to the source. 


\begin{abstract}
About the Center for Retirement Research
The Center for Retirement Research at Boston College, part of a consortium that includes parallel centers at the University of Michigan and the National Bureau of Economic Research, was established in 1998 through a grant from the Social Security Administration. The Center's mission is to produce first-class research and forge a strong link between the academic community and decision-makers in the public and private sectors around an issue of critical importance to the nation's future. To achieve this mission, the Center sponsors a wide variety of research projects, transmits new findings to a broad audience, trains new scholars, and broadens access to valuable data sources.
\end{abstract}

Center for Retirement Research at Boston College

Hovey House

140 Commonwealth Ave

Chestnut Hill, MA 02467

Tel: 617-552-1762 Fax: 617-552-0191

http://crr.bc.edu

Affiliated Institutions:

The Brookings Institution

Syracuse University

Urban Institute 


\begin{abstract}
Older Americans have been retiring later for a number of reasons, including jobs that are becoming less physically demanding, the shift from defined benefit to defined contribution pensions, and changes in Social Security's incentives. What are the implications of working longer for workers' mortality and health? Answering this question is complicated, because work and health are jointly determined - healthy people with lower mortality tend to work longer. Previous studies looking at the causal effect of work on mortality and health have found mixed results and have tended to focus on the effects of early retirement, not delayed retirement. A simple assumption would be that the relationship between them is symmetric. But it is unclear that that assumption is correct - after all, people who decide to keep working are likely a healthier group than those who stop early. This paper uses administrative data from the Netherlands and exploits policy variation designed to delay retirement to explore the links between work and health outcomes.
\end{abstract}

The paper found that:

- Working longer is associated with lower mortality, depression, and diabetes risk for both men and women in ordinary linear regression models.

- In an instrumental variable approach that takes into account the joint relationship between work and mortality, delayed retirement reduces the 5-year mortality rate for men ages $62-65$ by 2.4 percentage points, or a 32-percent reduction relative to nonworkers.

- $\quad$ However, the same analysis finds no significant relationship between delayed retirement and the health conditions studied.

- $\quad$ The effect on male life expectancy depends on how permanent the effect is. A 32percent reduction in mortality increases age-60 life expectancy by about three months if the effect applies only to the ages studied, but longer if the effect is permanent.

- $\quad$ For women, the weakness of the instrument variable results in insignificant results.

The policy implications of the findings are:

- $\quad$ Policies that delay retirement may increase longevity, especially for men, but have no detectable effect on depression or diabetes during one’s 60s. 
- As they consider policies that could lengthen careers, policymakers could take into account the possibility that lives may also be extended, and consider the potential effects on the benefits paid out. 


\section{Introduction}

Labor force participation rates among older Americans have been rising over the past 20 years for a variety of reasons, including the extension of the Social Security Full Retirement Age, the shift from defined benefit to defined contribution pensions, and the fact that jobs are becoming less physically demanding (e.g. Munnell 2015; Coile 2018). As workers postpone their retirement, what are the implications for workers' health, as measured both by mortality an important outcome for the fiscal situation of programs like Social Security - and for less acute health outcomes?

Answering this question is complicated, because work and health are jointly determined healthy people with lower mortality tend to work longer. To deal with this issue, the literature has applied instrumental variable techniques to uncover the causal relationship between work and mortality and other health measures, but with mixed results (Lindeboom et al. 2002; Dave et al. 2008; Coe and Lindeboom 2008; Kuhn et al. 2010; Hernaes 2013; Hallberg 2015; Bloemen et al. 2017; Fitzpatrick and Moore 2018). Moreover, the studies have not been well-suited to answer the question of how delayed retirement affects these outcomes, because they have tended to focus on the effects of policies that induce early retirement. A simple assumption would be that the relationship is symmetric - if early retirement decreases mortality then delayed retirement increases mortality - but it is unclear that that assumption is correct. After all, people making the decision to keep working are likely a healthier group than those who are deciding to stop early. Furthermore, prior studies have tended to focus on a specific sector or birth cohort, not the general population, making it difficult to extend results to the broad population of workers affected by policies that, explicitly or implicitly, encourage later retirement. In other words, the literature does not offer much insight into what will happen to individuals in their 60s should policies push them to work longer.

This project seeks to shed some light on this topic by exploiting a policy that has induced delayed retirement among early Baby Boomers in the Netherlands. Although the analysis focuses on the Dutch instead of the U.S. population, the policy affected people across all sectors of the economy - a population more similar to those affected by the far-reaching impact of U.S. Social Security reforms. Specifically, this paper uses a confidential, administrative panel dataset showing how health among older workers in the Netherlands changed after the introduction of the “Doorwerkbonus” (DWB), a tax-reduction program that encourages Dutch workers to delay 
retirement. The paper focuses on 5-year mortality rates, but also examines less acute health measures; because of the data lack information on actual medical diagnoses, the analysis uses information on prescription drug utilization tied to two specific conditions affecting mental and physical health - depression and diabetes. The analysis estimates the causal effect of delayed retirement using the exogenous variation in the timing of this policy - which previous work has found to delay retirement, especially among men - to estimate the effect of work on these health outcomes. ${ }^{1}$

The paper proceeds as follows. The next section reviews the literature on the relationship between retirement and health, and provides background on the Dutch institutional setting. The third section describes the Dutch administrative data and the econometric strategy used in this study. The fourth section discusses the results. The final section concludes that among those induced by the DWB policy to delay retirement, the 5-year mortality rate for men ages 62-65 was significantly lower, but there is no significant effect on depression and diabetes. Results for women are insignificant, largely because the instrument is weak since the DWB did not induce many women to delay retirement. The magnitude of the effect for men represents about a 32 percent reduction in 5-year mortality compared to non-workers, and has the potential to add about 3 months to the age-60 life expectancy if the reduction affects only the ages studied, and more if the reduction is permanent. While this increase is not large, this paper suggests that retirement policies that change the Social Security program in a way that extends careers may also extend lives and ultimately the period in which benefits are paid out.

\section{Background}

This section first reviews prior research on the relationship between work and health outcomes. The section then describes the pension system and labor force participation in the Netherlands, and discusses the policy used in this paper to analyze the causal relationship between work and health.

\section{Prior Literature on Work and Health Outcomes}

Although a rich literature has examined the relationship between work and health, distinguishing the causal effect has proved difficult and findings have been mixed.

\footnotetext{
${ }^{1}$ See Zulkarnain (2015) and Zulkarnain and Mastrogiacomo (2017).
} 
Two examples from recent studies illustrate the issue. The first, Bloemenet al. (2017), exploit an early retirement opportunity among civil service workers in their 50s in the Netherlands (in contrast to the DWB, which affects a broader group of workers across sectors). The study finds that early retirement decreased the affected group's 5-year mortality rate by 2.6 percentage points - an extremely large decrease given 5-year mortality was only about 3-4 percent at those ages in the first place. The second study, Kuhn et al. (2010), finds that bluecollar workers in Austria who were given an early retirement opportunity in their early 60s experienced an increase in the probability of dying before the age of 67 of 2.4 percentage points per year of early retirement. In other words, these papers found effects in the opposite directions. $^{2}$

Similarly, the literature that has studied other health outcomes also found mixed results. For example, while Dave et al. (2008) find that retirement leads to worse mental health, while others find positive mental health effects from retirement (e.g. Charles 2002; Neuman 2008; Eibich 2015). ${ }^{3}$

Aside from the mixed results, studies tend to only provide insight into specific sectors of the economy, i.e. the public sector in Bloemen et al. (2017) and blue-collar workers in Kuhn et al (2010), instead of into the broad range of occupations affected by programs such as the DWB or Social Security. ${ }^{4}$ Furthermore, despite the fact that most recent policies have encouraged later retirement, these studies have tended to focus on the effects of earlier retirement. ${ }^{5}$ Inferences from this literature on the effect of delayed retirement implicitly assume that delayed retirement

\footnotetext{
${ }^{2}$ Other evidence on the relationship between early retirement and mortality is also mixed. Coe and Lindeboom (2008) find no significant effect of early retirement on mortality in the HRS, but the point estimate suggests that early retirement before age 62 reduces the 4-year mortality risk by 5 percentage points. Kalwij et al. (2013) find that early retirement among the general population of the Netherlands is not significantly associated with higher mortality risk, except among those who use DI as an early retirement pathway. Hernaes et al. (2013) find no significant effect of early retirement before age 67 in Norway, but the point estimates suggest that a year of earlier retirement reduces mortality by age 67 and age 70 by 0.2 percentage points, mortality by age 74 by 2.5 percentage point, and mortality by age 77 by 6.6 percentage points. Hallberg et al. (2015) finds that early retirement among Swedish military officers in their 50s reduces the probability of dying before age 70 by 26 percent using a hazard model. Fitzpatrick and Moore (2018) find that the "early" eligibility age for U.S. Social Security increases male mortality at age 62 by about 2 percent. They estimate that early retirement increases mortality by 62 percent. They find no statistically significant effect for women.

${ }^{3}$ A related paper finds that a pension reform, which reduced the replacement rate among public sector workers, led to deteriorations in mental health (De Grip at al. 2018).

${ }^{4}$ Examples of studies that study the effects across the general population are Hernaes (2013), who looks at all Norwegians born between 1928-1938, Coe and Lindeboom (2008) and Fitzpatrick and Moore (2018) who study Americans across all industries. All three studies however study the effect of early retirement options.

${ }^{5}$ One study that does focus on delayed retirement is Hagen (2018), who studies delayed retirement among Swedish women, and finds no effect on health care utilization and mortality.
} 
would have the same effect, just in the opposite direction. This project contributes to this literature by exploiting a Dutch policy that induced delayed retirement for which people across all sectors were eligible - a group that is more similar to those affected by the far-reaching impact of U.S. Social Security reforms. To understand how the Dutch policy fits into the institutional setting, the next section describes the pension system in the Netherlands.

\section{The Pension System of the Netherlands}

The pension system in the Netherlands has three pillars. The first pillar is a national payas-you-go pension called the Algemene Ouderdomswet (AOW), established in 1957 and available to all individuals who have lived in the Netherlands for at least 50 years. ${ }^{6}$ The AOW provides a basic income linked to the minimum wage for everyone above the eligibility age, which was 65 for the cohorts studied in this paper. ${ }^{7}$ Benefits do not vary across people; for a single person, benefits are equal to 70 percent of the minimum wage (about EUR 1,000 per month), and 100 percent of the minimum wage for a couple (about EUR 1,400 per month). Claiming is automatic, cannot be claimed early or delayed, and does not require actual retirement from the labor force. ${ }^{8}$ Compared to other countries, the state pension provides only a small portion of retirement income in the Netherlands.

While the first pillar serves all Dutch citizens regardless of their work situation, the second two pillars are more person and job specific. The second pillar consists of collective employer-provided pensions. Although no law requires individuals to join pension funds, the government can make it mandatory for an entire industry or profession to provide a pension if representatives of employers and employees (e.g. unions) within the industry decide to offer one. As a result, over 90 percent of employees take part in a collective pension plan. In most plans, workers accrue either 1.75 percent of final salary or 1.75 to 2.25 percent of average salary per year of service. The third pillar is made up out of private, individual pension products. This

\footnotetext{
${ }^{6}$ Benefits are reduced by $1 / 50$ for each year a person lived outside of the Netherlands.

${ }^{7}$ For people born before 1948, the eligibility age (NRA) was 65. Starting in 2013, it has been increased by 1 to 3 months per birth cohort starting in 2013, so that the NRA is 66 in 2018 and 67 in 2021. After 2022, it will be linked to life expectancy.

${ }^{8}$ The Employee Insurance Agency (Sociale Verzekeringsbank) invites people to apply for benefits through a simple online process six months before reaching the NRA. When an application is filed late, benefits will be paid retroactively for up to 12 months, and in certain cases for more.
} 
pillar allows employees in sectors without a collective pension scheme or self-employed workers to build up savings, although anyone can purchase these products.

While the normal retirement age in the three pillars of the Dutch system was 65 before 2012, labor force participation among older workers in the Netherlands has been low since the 1980s and 90s (Kapteyn and De Vos 1999). For example, in 2006, only 34.6 percent of Dutch men and 19.8 percent of Dutch women between 60 and 64 were working (OECD 2018). This low labor force participation has been attributed to one feature of the second retirement pillar, namely the availability of so-called "early retirement plans," which allowed retirement from as early as 59. ${ }^{9}$ These schemes, originally intended to create employment opportunities for younger workers, made it possible for older workers to claim pensions and retire early, until they reached an age when their pension income would be supplemented by AOW benefits (Euwals et al. 2010). Additionally, Dutch regulations facilitated the use of disability insurance (DI) and unemployment insurance (UI) as pathways to early retirement (Kapteyn and De Vos 1999; Kerkhofs et al. 1999; Lindeboom 1998).

Over the past few decades, the Netherlands introduced policies to address the low labor force participation among older workers. Since the mid-1990s, early pension schemes have been phased out and sometimes replaced with pre-pension schemes that allow retirement before the Normal Retirement Age (NRA) (Euwals et al. 2010). ${ }^{10}$ Starting in 2002, retirement through DI and UI was made more difficult, and in 2006 laws governing early retirement reduced the generosity of plans for cohorts born after 1950 (De Vos et al. 2012). Still, because the AOW system is funded through a payroll tax and, given the aging of the Baby Boom cohorts, the Dutch government has continued its push toward longer careers for older workers. Part of this push is the policy exploited in this paper, the "Doorwerkbonus."

\section{The Doorwerkbonus}

Introduced in January 2009, the Doorwerkbonus (DWB) offers a reduction in taxes on labor income for each year in which a person worked after age 62 - effectively, a temporary

\footnotetext{
${ }^{9}$ The early retirement plans are called "VUT" schemes, which stands for "Vervroegde Uittreding en PrePensioen" - in English, "early exit and pre-pension.”

${ }^{10}$ Exact retirement rules of collective pension funds, including pre-pension eligibility ages and potential work restrictions, are negotiated between unions and employer organizations and may differ by pension fund. Dutch administrative data reveals that about 60 percent of men that work between age 62 and 65 also receive a pension.
} 
wage increase for older workers (Euwals et al. 2009). Table 1 shows the DWB structure and maximum bonus amounts by age in the top panel, and the labor income cap and floor in the bottom panel. At age 62, workers are eligible for a bonus of 5 percent of their taxable income, up to a maximum (EUR 2,296 in 2009). The DWB percentage rises with age until age 64, and decreases thereafter, down to 1 percent for ages 67 and up. The bonus payout rates remained the same from 2009 through 2011 but were amended in 2012. The policy was repealed in 2013 and replaced by a less generous bonus aimed at people 61-64. The DWB has been shown to be effective at encouraging work among people in their 60s - Zulkarnain (2015) found that it increased male labor force participation for men ages 62-64 by about 4.5 percentage points on average, with smaller effects for women (about a 1-percentage-point increase in labor force participation) (Zulkarnain and Mastrogiacomo 2017).

\section{Data and Methodology}

To study the relationship between delayed retirement and mortality, depression, and diabetes, this paper exploits the introduction of the DWB in 2009 as a natural experiment, encouraging some people to work longer based solely on their birth cohort. To perform the analysis, the paper uses a confidential administrative longitudinal dataset, collected by Statistics Netherlands, covering the entire population from 1999-2016. The data consist of high-quality administrative records on labor market outcomes, income and benefit receipt, marital status, and dates of death. Although the data do not contain information on medical conditions - perhaps the preferred way to measure health - they do include prescription drug use, which can serve as an indicator of certain conditions. All of this information is linked together by a personal identifier.

The sample for this study includes men and women born between 1943 and 1954, whose labor force participation and other characteristics are studied between 1999 and 2011. Of primary interest is mortality in the 5-year period after observation, for which mortality data through 2016 is used. For less acute measures of health, the study will focus on one psychological and one physical health condition: 1) depression; and 2) diabetes, using prescription drug data available from 2006 through 2016. These two conditions were chosen because they could be mapped to prescription drug classes as recorded by the Anatomical 
Therapeutic Chemical (ATC) Classification System more directly than most other conditions. ${ }^{11}$ Because diabetes is persistent and few people recover from it, the analysis focuses on the effect of working longer on the onset of diabetes, by restricting the analysis sample to people were not prescribed any prescription drugs for diabetes in the first year the data is available.

Because the DWB policy had little effect among cohorts born before 1946 (Zulkarnain 2015; Zulkarnain and Mastrogiacomo 2017), the analyses focus on the effects of the policy among cohorts born between 1946 and 1949 (Table 2). ${ }^{12}$ Because the cohorts born between 1943 and 1945 are being used as a control cohort, observations from people in these cohorts are dropped after 2009, when they also became eligible for the DWB. ${ }^{13}$

Disentangling the causal relationships between continued work and health outcomes is complex, because work and health are jointly determined. The observation that individuals who are not working die earlier or have worse health outcomes could be the result of three different causes: 1) bad health could trigger workers to retire earlier; 2) retirement itself could negatively affect health; or 3) a third, unobserved factor could both decrease health and trigger retirement, such as a job loss or spousal health shock. The consequence is that the simple Ordinary Least Squares (OLS) regression equation below is likely to produce results that do not actually capture a causal relationship:

$$
D_{i, t+5}=\alpha+X_{i t}^{\prime} \beta+\gamma \text { Working }_{i t}+\delta y e a r+A_{k}+Y_{m}+S_{n}+\varepsilon_{i t}
$$

In equation (1), the dependent variable $D_{i, t+5}$ is an indicator for whether, within the next five years, the person 1) dies; 2) is prescribed antidepressants; or 3) is prescribed diabetes

\footnotetext{
${ }^{11}$ The data has information on whether a person was prescribed a prescription drug in an ATC4 drug class. ATC4 codes includes anatomical (consisting of 1 letter), therapeutic (consisting of 2 digits), and pharmacological (consisting of 1 letter) information. For example, in the code N06A, N indicates the Nervous System, and 06 indicates that it is a Psychoanaleptics. Together, the code N06A indicates Antidepressants, which the study uses to create the depression indicator. The study also combines A10A, for Insulins and analogues, A10B, for blood glucose lowering drugs, excluding insulins, and A10X for other diabetes drugs to create the diabetes indicator. ${ }^{12}$ The younger cohorts are included in the sample to help capture secular trends in health and the labor market. ${ }^{13}$ The study estimates the effect of working on the 5-year mortality risk. The 5-year mortality risk at age 63 of persons born in 1945 could also been affected because of eligibility for the DWB after 2009. However, labor force participation among these cohorts at these ages was low (below 30 percent), and take up among the older cohorts was likely low (Zulkarnain 2015). Eligibility for the DWB among these cohorts would bias the estimates towards zero.
} 
medication. A five-year period is chosen for the analysis simply because this is the maximum length of time we can observe all individuals in the sample. ${ }^{14}$ Working is an indicator for whether person $i$ is working in year $t{ }^{15}$ The base specification includes a vector $X_{i t}^{\prime}$ with controls for marital status, for income in 1999, for whether the person was in a DWB-eligible cohort, or in a younger birth cohort. ${ }^{16}$ It also includes $A_{k}$, a vector of age fixed effects, where $k$ ranges from age 51 to age 65, and $Y_{m}$ a vector of year fixed effects, where $m$ ranges from 2000 to 2011. Alternative specifications include a vector of industry fixed effects, $S_{n}$, and controls for whether a person receives a pension, welfare, UI, DI or other social benefits. ${ }^{17}$ Because the prescription drug data is available only from 2006, models of depression and diabetes only include observations between 2006 and 2011. A negative coefficient $\gamma$ would suggest that continued work reduces the risk of mortality, depression, or diabetes. But since health and work are jointly determined as was discussed above, that conclusion could be misleading.

To address the issue of endogeneity in equation (1), the project exploits the introduction of the DWB policy in an instrumental-variable model, using a two-stage least squares (2SLS) framework to estimate the causal effect of continued work between ages 62 and 65 on the health outcomes. ${ }^{18}$ The first stage in this empirical strategy estimates the following equation:

\footnotetext{
${ }^{14}$ The data has information for whether a person was prescribed a prescription drug in an ATC4 drug class. The study uses N06A, the code for antidepressants, and combines A10A, for Insulins and analogues, A10B, for blood glucose lowering drugs, excluding insulins, and A10X, other drugs used in diabetes to create the diabetes indicator. ${ }^{15}$ Statistics Netherlands bases labor market status on the largest income source each month.

${ }^{16}$ While secular increases in education could be correlated with both working longer and mortality (Kalwij, Kapteyn, and De Vos 2018) it may be less of a concern in the current setting, due to the narrow range of cohorts studied and because a linear control for calendar year adjusts would for secular trends. Ideally, an education control would ideally be included, however, Statistics Netherlands does not have education information for these cohorts. The regression includes income in 1999 as a proxy for education. Some specifications also include binary controls for receipt of pension, UI, DI, Welfare or other social benefits.

${ }^{17}$ Industry is either the industry that the person is currently working in, or the last industry the person was observed working in. Because many employer-provided pensions are industry-wide pensions, the industry fixed effects control for potential (unobserved) differences in exact retirement rules between industries.

${ }^{18}$ The instrument needs to satisfy the following three conditions to be valid: 1) it needs to be effectively randomly assigned; 2) it needs to be not directly related to mortality and health; and 3) it needs to affect labor force participation. The DWB instrument satisfies these criteria. First, because eligibility for the DWB policy is based on age, which is out of any individual's control, it can be seen as randomly assigned. Second, mortality and health should not be directly affected by eligibility for the DWB policy; the aging process decreases health and increases mortality risk, but not differentially for those who were in the cohorts eligible for the DWB after controlling for time. While the income effect could theoretically affect mortality directly, the maximum amount of $€ 10,000$ over three years is not likely to have a significant effect. Furthermore, the literature has found little evidence of a causal effect of income on mortality (e.g. Lindahl 2005; Snyder and Evans 2006; Schnalzenberger 2011; Ahammer et al. 2017). Third, Zulkarnain (2015) and Zulkarnain and Mastrogiacomo (2017) show that the policy increased labor force participation.
} 


$$
\text { Working }_{i t}=\pi+X_{i t}{ }^{\prime} \rho+\lambda D W B_{i t}+A_{k}+Y_{m}+S_{n}+\eta_{i t}
$$

where $D W B$ is a binary indicator for whether a person was eligible for the bonus, which is 1 for any individuals observed in 2009 or later from the 1946-1949 cohorts. Results from Zulkarnain (2015) suggest that coefficient $\lambda$ is positive - that is, the policy exogenously increased working. The second stage is:

$$
D_{i, t+5}=\mu+X_{i t}^{\prime} \vartheta+\phi \text { Wrkıng }_{i t}+A_{k}+Y_{m}+S_{n}+v_{i t}
$$

where W $_{\text {orkıng }}$ it is the predicted working status from the first stage and the other variables are as defined above. The coefficient $\phi$ gives the local average treatment effect (LATE) of continued work on mortality, depression, and diabetes - that is, the effect of delayed retirement on these outcomes among those who were induced to work longer by the DWB policy. ${ }^{19}$

A potential concern with the study design is the occurrence of the Great Recession, which coincided with implementation of the DWB. Although the effects of the DWB could be confounded by changing labor market conditions during this time, the Dutch unemployment rate was relatively stable between 2006 and 2009 (see Appendix Figure 1). The unemployment rate in the Netherlands fell from 6.1 percent in early 2006, to 3.7 percent in late 2008. The rate started rising in 2009, but remained below early 2006 levels until spring 2012. Another concern is that the sample includes individuals in their early 60s, regardless of their employment status in their 50s. While the DWB policy induced people to delay retirement, it was not very effective in inducing people to return to work after retirement. A robustness check will assess whether those induced by the policy to return work experienced differential effects compared to those who were in the labor force throughout their 50s. Finally, the paper will assess the extent to which the decision to control for baseline income affects the results, as income could be endogenous.

\footnotetext{
${ }^{19}$ The models are estimated with robust standard errors to correct for potential heteroskedasticity in the error terms,
} and are clustered at the birth cohort-year level to control for serial correlation of the error terms. 


\section{Results}

This section first presents the descriptive differences in mortality, depression, and diabetes risk between workers and non-workers and between those eligible for the DWB and those who are not eligible. The section then presents the OLS regression results and 2SLS results for mortality, including robustness checks when relevant, followed by the OLS and 2SLS results from the models of depression and diabetes.

\section{Unadjusted Differences in Mortality, Depression, and Diabetes Risk}

Tables 3a and 3b show unadjusted mortality, depression, and diabetes rates and other descriptive statistics for men and women respectively based on their work status and on eligibility for the DWB. The main takeaway is that the 5-year mortality and depression risks for men who were not working at ages 62 - 65 were 3-4 percentage points higher than for those who were working, both before and after the DWB took effect, while the diabetes risk was 1 percentage point higher. For women, the mortality gap was slightly smaller, at roughly 2 percentage points, while the depression and diabetes gaps were 5-6 percentage points for depression, and at 2 percentage points for diabetes. Figures 1a and 1b plot out the gap in 5-year mortality between non-workers and workers for men and women over time and show that while mortality improved across the board (albeit less so for women), the gap between the two groups has remained relatively stable. For diabetes and depression, the gaps between working and nonworking men and women have also been roughly stable, with perhaps slight growth in the gap for men. Other characteristics by working status shown in Tables 3a and 3b are as expected. For example, men who do not work are more likely to receive a pension, UI, DI, welfare, and other social benefits.

The main contention of this paper is that the gap in mortality, depression, and diabetes between workers and non-workers seen in Tables 3a and 3b and illustrated in Figures 1a, 1b, 2a, 2b, 3a, and 3b may overstate the actual effect of working on these outcomes. The instrumental variables approach is designed to deal with this issue, but requires that the DWB actually impacts work through longer careers. Figures $4 \mathrm{a}$ and $4 \mathrm{~b}$ show, for men and women respectively, that the policy did impact the propensity to work, especially at ages 62 - 64, although the effect for women is smaller. For example, just under half of the men were working at age 62 before the introduction of the DWB (2006-2008), but that increased to 60 percent after the introduction 
(2009-2011). However, the difference in labor force participation by DWB status at age 65 is much smaller than at older ages (consistent with Zulkarnain 2015).

\section{Mortality}

This section first presents the OLS results, then the 2SLS results, and finally robustness checks for the outcome of mortality.

OLS Regression Estimates. The paper will first focus on the relationship between working and mortality, the ultimate measure of health. Before proceeding to the 2SLS regressions, it is useful to examine the OLS regressions of mortality on working to see if observable characteristics alone can explain the gap described above. Table 4 shows the estimates from equation (1) where the dependent variable is an indicator for dying within five years and the key independent variable is the indicator for working among men (first three columns) and women (latter three columns). The results in the first and fourth columns include only controls from the base specification. The second and fifth columns show results from models that also include industry fixed effects. The results in the third and sixth columns are also adjusted for whether someone receives a pension, welfare, unemployment, disability, or other social benefits. Full results are available in Appendix Table A1a and b.

The results in Table 4a confirm the earlier unadjusted evidence that, even after controlling for differences between working and non-working men, working is associated with lower mortality risk for men and for women. The first column of Table 4a shows that men who work are 2.4 percentage points less likely to die in the following five years, while women are 1.4 percentage points less likely to die. Including industry fixed effects does not affect the coefficients for men, and only slightly reduces it to a difference of 1.3 percentage points in 5year mortality risk for women (column 2). The association is reduced to 2 percentage points and 0.8 percentage points, respectively, after including additional controls for pension receipt and social benefits, although the results remain statistically significant.

Mortality 2SLS Regression Estimates. To control for the fact that people who work longer may also live longer for other reasons that cannot easily be controlled for, the analysis exploits the introduction of the DWB policy as an instrument in a two-stage-least squares 
framework. Table $4 \mathrm{~b}$ shows the second-stage estimates from this regression, where the indicator for dying within the next five years is again the outcome of interest and work status is instrumented with DWB eligibility among men (first three columns) and women (latter three columns). ${ }^{20}$ These estimates represent the Local Average Treatment Effect (LATE) of working on one's 5-year mortality risk for men and women induced by the DWB to remain in the workforce. The bottom panel reports the coefficient on the DWB indicator and the first-stage Fstatistic; the higher the F-statistic, the stronger the DWB predicted work behavior. ${ }^{21}$

The controls for benefits may be somewhat endogenous, since DI receipt is likely correlated with labor force participation and mortality; therefore, the second specification is preferred. The results from the second specification (second column of Table 4a) shows that working reduced 5-year mortality risk by 2.4 percentage points for men who were induced into working by the DWB, or a 32-percent reduction relative to the average mortality risk of nonworking men. While a 32-percent reduction appears large, it is much smaller than the estimates from the literature discussed above. To put these estimates into better context, a 32-percent reduction in the 5-year mortality risk at these ages would increase life expectancy at age 60 from 21.5 to 21.8 years - an increase of about 3 months. ${ }^{22}$ Of course, if the effect instead were to last beyond these ages, the increase in life expectancy would be larger. ${ }^{23}$ For women, the 2SLS analysis finds no significant change in the probability of death among those induced to work longer because of the DWB.

For women, the effect in Table 4a vanishes, suggesting that none of the causal effect remains. Still, this null result should be interpreted with caution, since the DWB instrument is weaker for women than for men (see the low F-statistics presented in Table 4b), meaning it is possible that the lack of significance is a consequence of the smaller relationship between the DWB and working for women than for men. In other words, the weakness of the first stage for women limits the interpretation of the second.

\footnotetext{
${ }^{20}$ Full results are available in Appendix Table A2a and b.

${ }^{21}$ The table reports the Kleibergen-Paap F statistic. The full 2SLS results are shown in Appendix Table A2a and A2b.

${ }^{22}$ Based on authors' calculations from the 2009 life table for Dutch men (WHO 2018).

${ }^{23}$ If the improvement would be permanent, authors' calculations suggest an increase in life expectancy of a little over 2 years.
} 
Robustness checks. Because instrumental variable regressions can be more sensitive than OLS to the underlying assumptions of the analysis, this section describes the results of robustness checks to ensure the results are sensible and hold up to changes in the assumptions. These robustness tests are performed only for men, for whom the 2SLS results were significant.

The first test has to do with the sample chosen in the initial analysis - namely the one that includes individuals in their early 60s regardless of their past employment status during their 50s. This choice is important, because while the DWB policy induced people to delay retirement, it was not effective in inducing people to return to work after retirement. In other words, people who were not working in their 50s were unlikely to be moved by the DWB to begin working. This could lead to a weaker effect than actually exists. To test whether those who were unlikely to be induced by the policy to work did not add noise to the estimates, column 3 in Table 4c shows the results from a sample limited to people who were working at age 55 . The point estimates are very similar to the result from the preferred model in column (1), corresponding to the result in column (2) from Table 4a, indicating this aspect of sample selection does not seem to be driving the results.

A second concern is that income itself might play an important role in the relationship between working and mortality and that the decision to control for income affected the results. ${ }^{24}$ Even though the specifications in Tables 4a and 4b controlled for income in 1999, which was the earliest period available in these data and thus the period least susceptible to the endogeneity, this control might still bias the estimated relationship between working and mortality. However, column 4 in Table 4c shows that leaving out the control for labor income in 1999 barely affects the estimate.

\section{Depression}

The previous results have shown that delaying retirement reduces the 5-year male mortality rate. In this and the next sections, the project explores whether this relationship also manifests itself through diagnoses of depression and diabetes, respectively. Table 5a shows the OLS results from a model where the dependent variable is an indicator for whether a person was

\footnotetext{
${ }^{24}$ While the positive correlation between income and longevity has been well documented (e.g. Kitagawa and Hauser 1973; Deaton and Paxton 1998; Chetty et al. 2016), the literature has either found no causal effect of income on mortality (Lindahl 2005; Schnalzenberger 2011; Ahammer et al. 2017) or a small negative effect (Snyder and Evans 2006).
} 
prescribed antidepressants within five years of observation. ${ }^{25}$ As in the mortality models, the key independent variable is an indicator for working men (first three columns) and working women (latter three columns). The results from the preferred specification (column 2) show that men who work are 5.5 percentage points less likely to suffer from depression within the next five years, while women who work are 6.4 percentage points less likely (column 5). Both results are statistically significant and represent a 48-percent reduction in depression risk relative to nonworking men, and a 35-percent reduction for women.

To control for the fact that people who suffer from depression may also be less likely to work for reasons that cannot easily be controlled for, the analysis again turns to the 2SLS framework (Table 5b). ${ }^{26}$ Focusing on results for men, since the DWB instrument remains too weak to establish causal effects of working longer for women, the findings indicate that working longer has no statistically significant effect on the 5-year depression risk for men. So while the OLS results suggest a strong significant negative association between working and depression, the 2SLS results finds no evidence of such a relationship.

\section{Diabetes}

Finally, the analysis examines the relationship between working longer and diabetes. The OLS findings in Table 6a show that men who work have a 1-percentage point lower 5-year diabetes risk (column (2)), while women who work have a 1.2 percentage point lower risk (column (5)). ${ }^{27}$ Both results are statistically significant and represent a 12-percent reduction in diabetes risk relative to non-working men, and a 19-percent reduction relative to non-working women.

Table 6b shows the 2SLS results. ${ }^{28}$ Again focusing only on men, due to the instrument being weak for women, these results indicate that working longer also has no statistically significant effect on the 5-year diabetes risk. Similar to the findings for depression, while the OLS estimates suggest that a strong negative association between working and diabetes exits, the 2SLS estimates show no evidence of such a causal relationship.

\footnotetext{
${ }^{25}$ Full results are available in Appendix Table A3a and b.

${ }^{26}$ Full results are available in Appendix Table A4a and b.

${ }^{27}$ Full results are available in Appendix Table A5a and b.

${ }^{28}$ Full results are available in Appendix Table A6a and b.
} 


\section{Conclusion}

The previous literature found mixed evidence of a relationship between early retirement and health outcomes, but has tended not to study the effects of delaying retirement, and has tended to focus on smaller segments of the population. This study contributes to the literature by exploiting a policy that induces delayed retirement instead of early retirement and by estimating the causal effect of continued work in one's early 60s among a broad cohort of early Baby Boomers in the Netherlands. The results from this study are inconclusive for women, but suggest that working at later ages reduces the 5-year mortality risk in the early-60s for men by about 30 percent relative to non-workers.

However, while the mortality effects for men would lead one to expect that working longer would also significantly reduce diagnosed health conditions, no significant relationship was found for depression or diabetes, the two conditions studied here, which suggests these conditions are not responsible for the mortality reduction. This result may stem from the fact that depression and diabetes are not as acutely life-threatening as other conditions might be. Further research is needed to determine the conditions through which the positive effect of working manifests itself. Such research would benefit from data on actual diagnoses, as opposed to the limited information available in prescription drug records. Additionally, the relationship between working and mortality may also manifest itself through a variety of conditions, making it difficult to find a significant result for any one condition.

Nevertheless, the results contribute to the discussion on the fiscal balance of social insurance systems like Social Security in the United States. If retiring later reduces mortality, it would also lengthen the period in which benefits are paid out. The extent to which reduced mortality would increase benefit expenditures depends on whether this mortality effect is limited to just the ages studied or is longer-lasting. A back-of-the-envelope calculation indicates that a temporary 32-percent reduction in the 5-year mortality during the ages studied increases life expectancy at age 60 by only about 3 months, which suggests a limited financial effect on the program. Of course, if the mortality effect is longer-lasting the financial effects would be larger.

This paper attempts to obtain causal estimates of the effect of working longer on mortality, but two caveats are in order. First, it should be noted that the estimated effects are specific to the people who responded to the DWB policy (because the estimate is a LATE) and may not translate to everyone retiring later. Second, the effect may not translate to a delayed 
retirement response in the United States from the current proposals affecting Social Security that might induce Americans to retire later. The reason is that the DWB provided an incentive to work longer in the form of a reward - a "carrot” approach, while current U.S. proposals under consideration tend to reduce benefits - that is, a "stick” approach.. Nonetheless, these results shed light on the potential mortality effects of policies that lead to delayed retirement, a relationship that policymakers may want to consider going forward. 


\section{References}

Ahammer, Alexander, G. Thomas Horvath, and Rudolf Winter-Ebmer. 2017. "The effect of income on mortality - new evidence for the absence of a causal link." Journal of Royal Statistical Society, Statistics in Society Series A 180: 793-816.

Bloemen, Hans, Stefan Hochguertel, and Jochem Zweerink. 2017. "The Causal Effect of Retirement on Mortality: Evidence from Targeted Incentives to Retire Early.” Health Economics 00:1-14.

Charles, Kerwin Kofi. 2004. "Is Retirement Depressing? Labor Force Inactivity and Psychological Well-Being in Later Life.” Research in Labor Economics 23: 269-299.

Chetty, Raj, Michael Stepner, Sarah Abraham, Shelby Lin, Benjamin Scuderi, Nicholas Turner, Augustin Bergeron, and David Cutler. 2016. “The Association Between Income and Life Expectancy in the United States, 2001-2014” The Journal of the American Medical Association 315(16):1750-1766.

Coe, Norma B. and Maarten Lindeboom. 2008. "Does Retirement Kill You? Evidence from Early Retirement Windows.” Discussion Paper 3817. Bonn, Germany: Institute for the Study of Labor (IZA).

Coe, Norma B. and Gema Zamarro. 2011. "Retirement Effects on Health in Europe.” Journal of Health Economics 30(1): 77-86.

Coile, Courtney. 2018. “Working Longer in the U.S.: Trends and Explanations” Working Paper 24576. Cambridge, MA: National Bureau of Economic Research.

Dave, Dhaval, Inas Rashad, and Jasmina Spasojevic. 2008. “The Effects of Retirement on Physical and Mental Health Outcomes.” Southern Economic Journal 75: 497-523.

Deaton, Angus S. and Christina H. Paxson. 1998. “Aging and Inequality in Income and Health.” American Economic Review 88(2), 248-253.

De Grip, Andries, Maarten Lindeboom, and Raymond Montizaan. 2012. "Shattered Dreams: The Effects of Changing the Pension System Late in the Game.” The Economic Journal 122: $1-25$.

De Vos, Klaas, Arie Kapteyn, and Adriaan Kalwij. 2012. "Disability Insurance and Labor Market Exit Routes of Older Workers in The Netherlands.” In Social Security and Retirement around the World: Historical Trends in Mortality and Health, Employment, and Disability Insurance Participation and Reforms, edited by David A. Wise. The University of Chicago Press, Chapter 12, p. 419-447.

Eibich, Peter. 2015. "Understanding the Effect of Retirement on Health: Mechanisms and Heterogeneity.” Journal of Health Economics 43: 1-12. 
Euwals, Rob, Ruud de Mooij, and Daniel van Vuuren. 2009. “Rethinking Retirement.” CPB Netherlands Bureau for Economic Policy Analysis.

Euwals, Rob, Daniel van Vuuren, and Ronald Wolthoff. 2010. "Early Retirement Behavior in the Netherlands: Evidence from a Policy Reform.” De Economist 158:209-246.

Fitzpatrick, Maria D., and Timothy J. Moore. 2018. “The Mortality Effects of Retirement: Evidence from Social Security Eligibility at Age 62” Journal of Public Economics 157: 121-137.

Hallberg, Daniel, Per Johansson, and Malin Josephson. 2015. ”Is an early retirement offer good for your health? Quasi-experimental evidence from the army.” Journal of Health Economics 44: 274-285.

Hagen, Johannes. 2018. “The effects of increasing the normal retirement age on health care utilization and mortality.” Journal of Population Economics 31(1): 193-234.

Hernaes, Erik, Simen Markussen, John Piggott, Ola L. Vestad. 2013. “Does Retirement Age Impact Mortality?” Journal of Health Economics 32: 586 - 598

Kalwij, Adriaan, Rob Alessie, and Marike Knoef. 2013. "Pathways to Retirement and Mortality Risk in the Netherlands.” European Journal of Population 29(20): 221-238.

Kalwij, Adriaan, Arie Kapteyn, Klaas de Vos. 2018. "Why are People Working Longer in the Netherlands.” Working Paper 24636. Cambridge, MA: National Bureau of Economic Research, Inc.

Kapteyn, Arie and Klaas de Vos. 1999. “Social Security and Retirement in the Netherlands”.in Social Security Programs and Retirement Around the World, edited by J. Gruber and D. Wise (eds.). Chicago, IL: University of Chicago Press. 269-303.

Kerkhofs, Maarten, Maarten Lindeboom and Jules Theeuwes. 1999. "Retirement, Financial Incentives and Health.” Labour Economics 6: 203-227

Kitagawa, E. M. and Hauser, P. M. 1973. "Differential Mortality in the United States: A Study in Socioeconomic Epidemiology.” Cambridge, MA: Harvard University Press

Kuhn, Andreas, Jean-Philippe Wuellrich and Josef Zweimueller. 2010. "Fatal Attraction? Access to Early Retirement and Mortality.” Discussion Paper 5160. Bonn, Germany: Institute for the Study of Labor (IZA).

Lindeboom, Maarten. 1998. "Microeconometric analysis of the retirement decision: The Netherlands.” OECD Economics Department Working Paper 107, Paris, OECD. 
Lindahl, Mikael. 2005. "Estimating the Effect of Income on Health and Mortality Using Lottery Prizes as an Exogenous Source of Variation in Income.” Journal of Human Resources 40(1): 144-168.

Munnell, Alicia H. 2015. “The Average Retirement Age: An Update,” Issue in Brief 15-4. Chestnut Hill, MA: Center for Retirement Research at Boston College.

Neuman, Kevin. 2008. "Quit Your Job and Get Healthier? The Effect of Retirement on Health.” Journal of Labor Research 29:177-201.

Organisation for Economic Co-operation and Development (OECD). 2018. "LFS by Sex and Age - Indicators.” OECD.Stat. Paris, France. Available at: https://stats.oecd.org/Index.aspx?DataSetCode=LFS_SEXAGE_I_R\#

Schnalzenberger, Mario. 2011. "Causal Effect of Income on Health: Investigating Two Closely Related Policy Reforms in Austria.” Working Paper 1109, Johannes Kepler Universität Linz, Department of Economics.

Snyder, Stephen E., and William N. Evans. 2006. "The Effect of Income on Mortality: Evidence from the Social Security Notch." Review of Economics and Statistics 88(3): 482-495.

World Health Organization. 2018. "Global Health Observatory Data Repository. Life Tables by Country.” Geneva, Switzerland. Available at: http://apps.who.int/gho/data/?theme=main\&vid=61160

Zulkarnain, Alice. 2015. "A Delayed Retirement Policy and Male Labor Supply: Evidence from the Entire Dutch Population.” 2015. Netspar Discussion Paper 12/2015-52.

Zulkarnain, Alice and Mastrogiacomo, Mauro. 2017. "The Effect of a Delayed Retirement Policy on Female Labor Supply: Evidence from the Entire Dutch Population.” Available at SSRN: https://ssrn.com/abstract=3172286 
Figure 1a. Five Year Mortality Rate for Men Ages 62-65, by Working Status

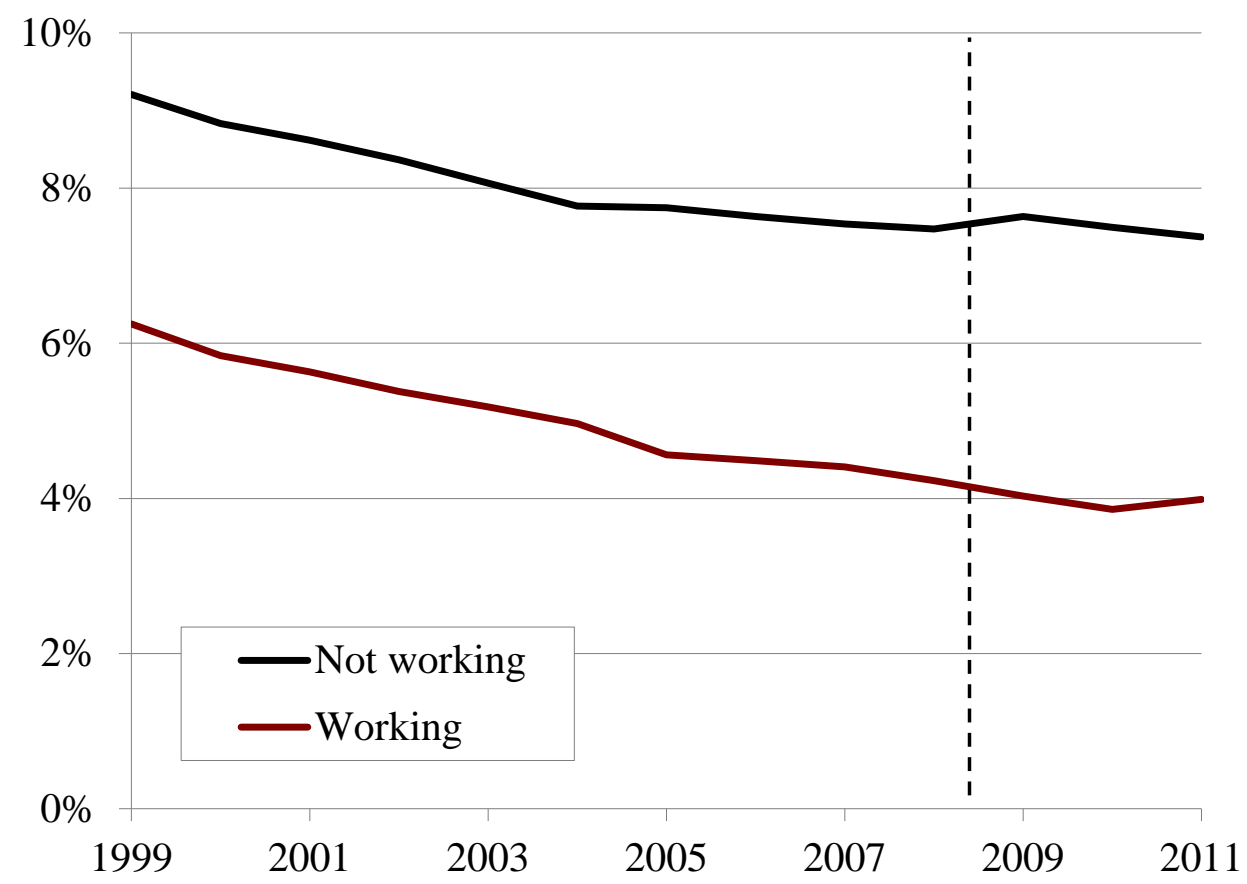

Figure 1b. Five Year Mortality Rate for Women Ages 62-65, by Working Status

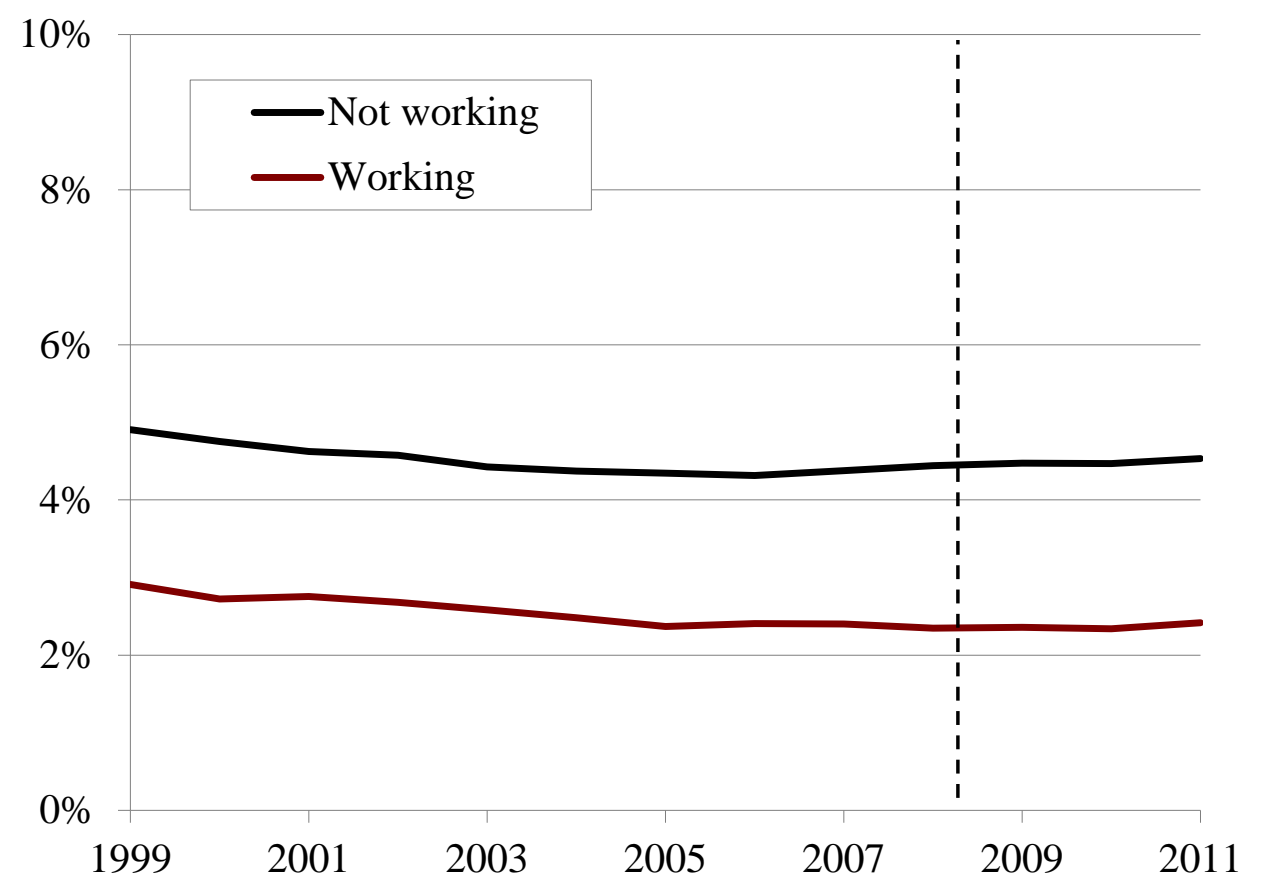

Source: Authors’ calculations using non-public microdata from Statistics Netherlands, 1999-2016. 
Figure 2a. Five Year Depression Rate for Men Ages 62-65, by Working Status

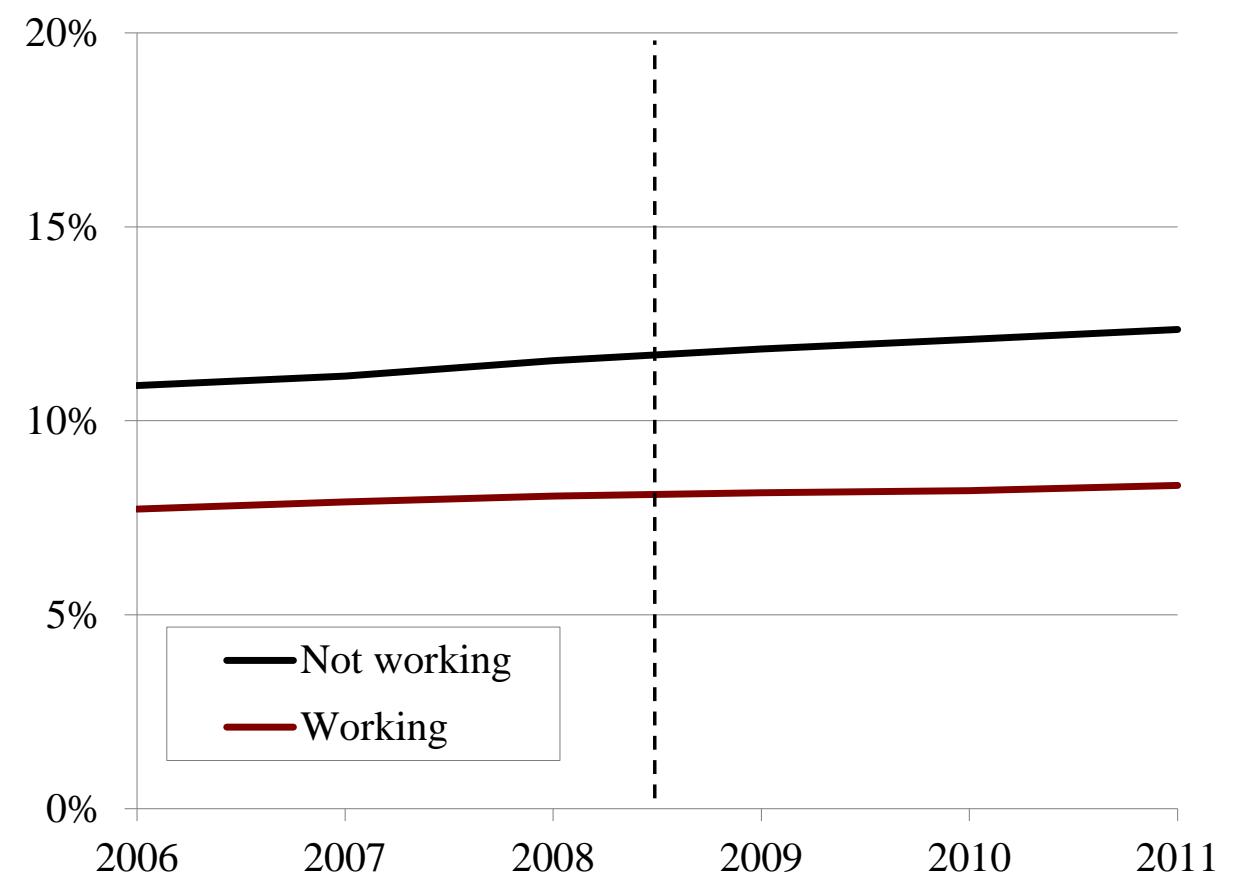

Figure 2b. Five Year Depression Rate for Women Ages 62-65, by Working Status

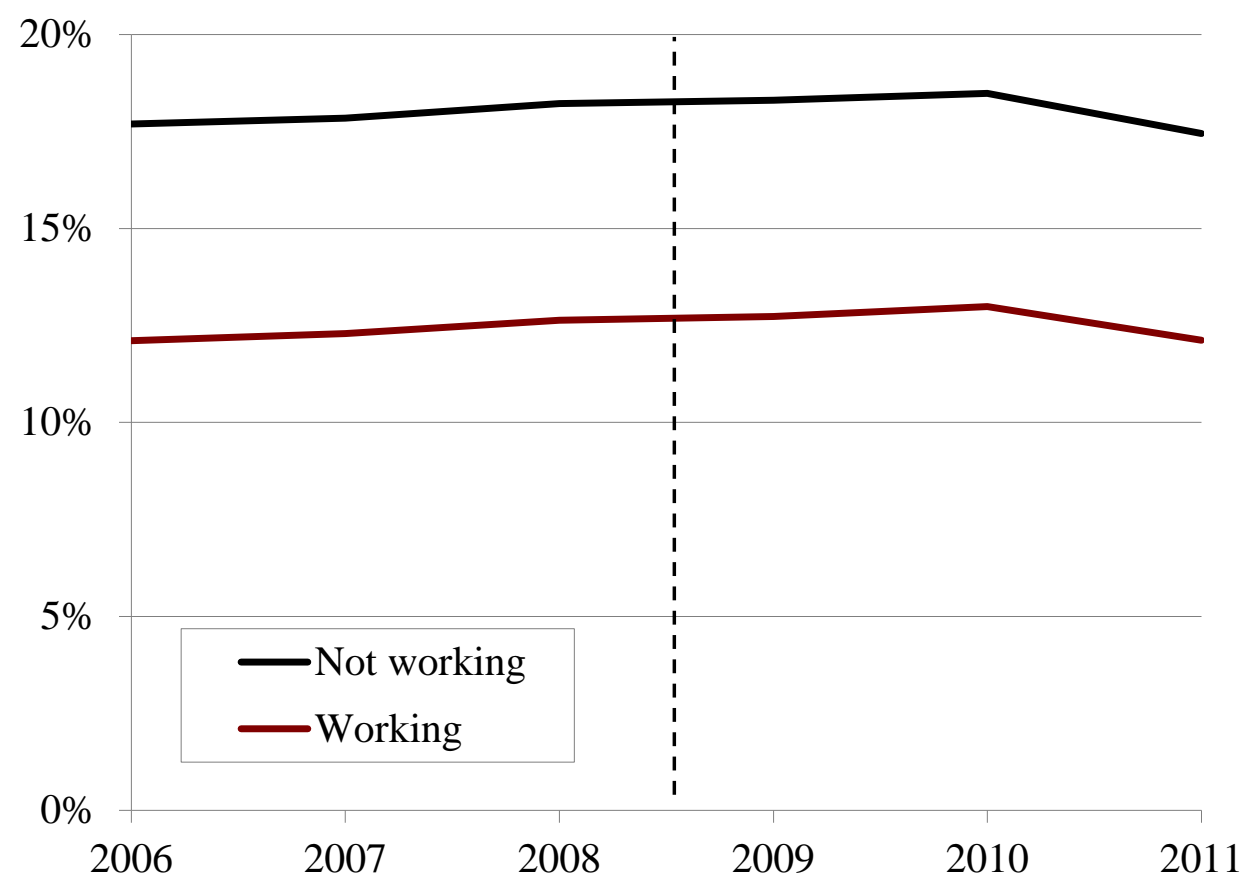

Source: Authors' calculations using non-public microdata from Statistics Netherlands, 2006-2016. 
Figure 3a. Five Year Diabetes-On-set Rate for Men Ages 62-65, by Working Status

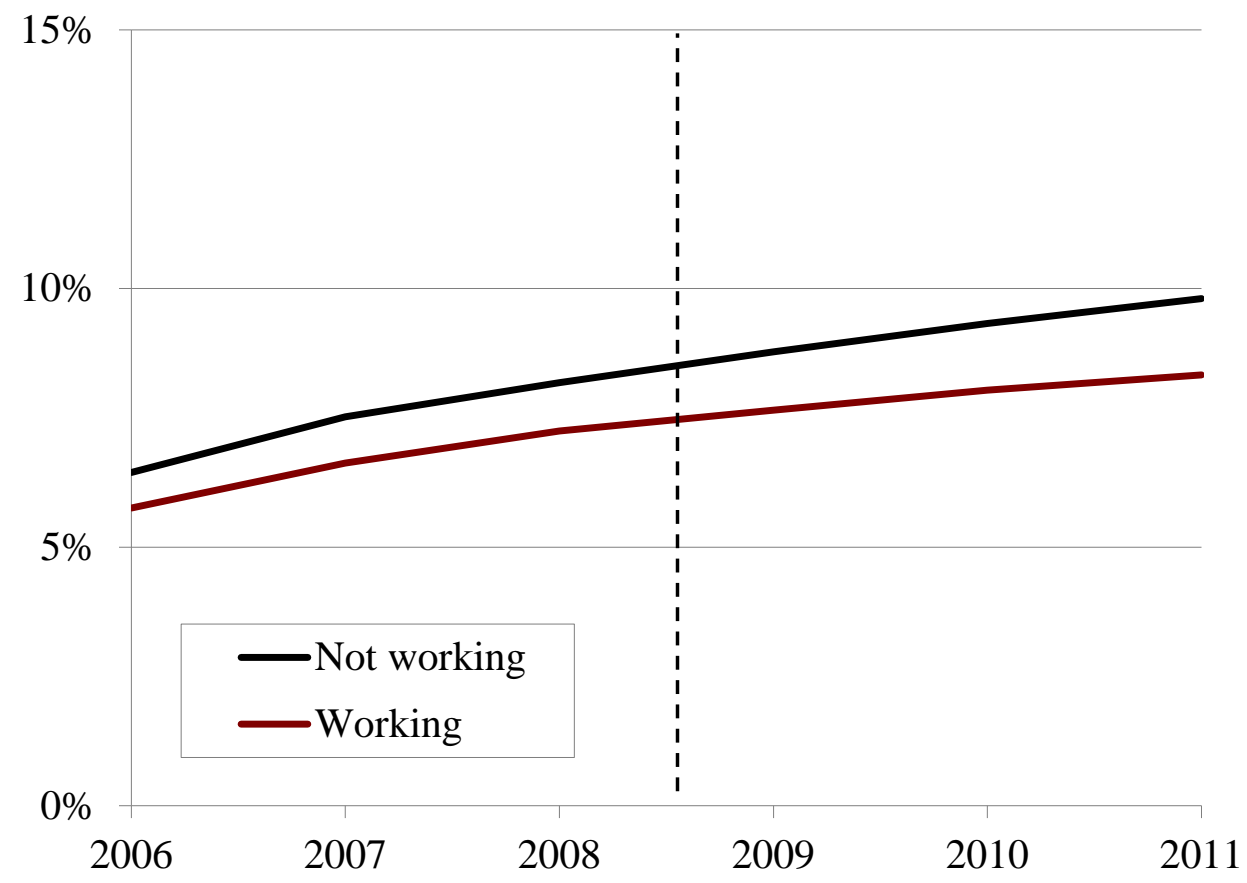

Figure 3b. Five Year Diabetes On-set Rate for Women Ages 62-65, by Working Status

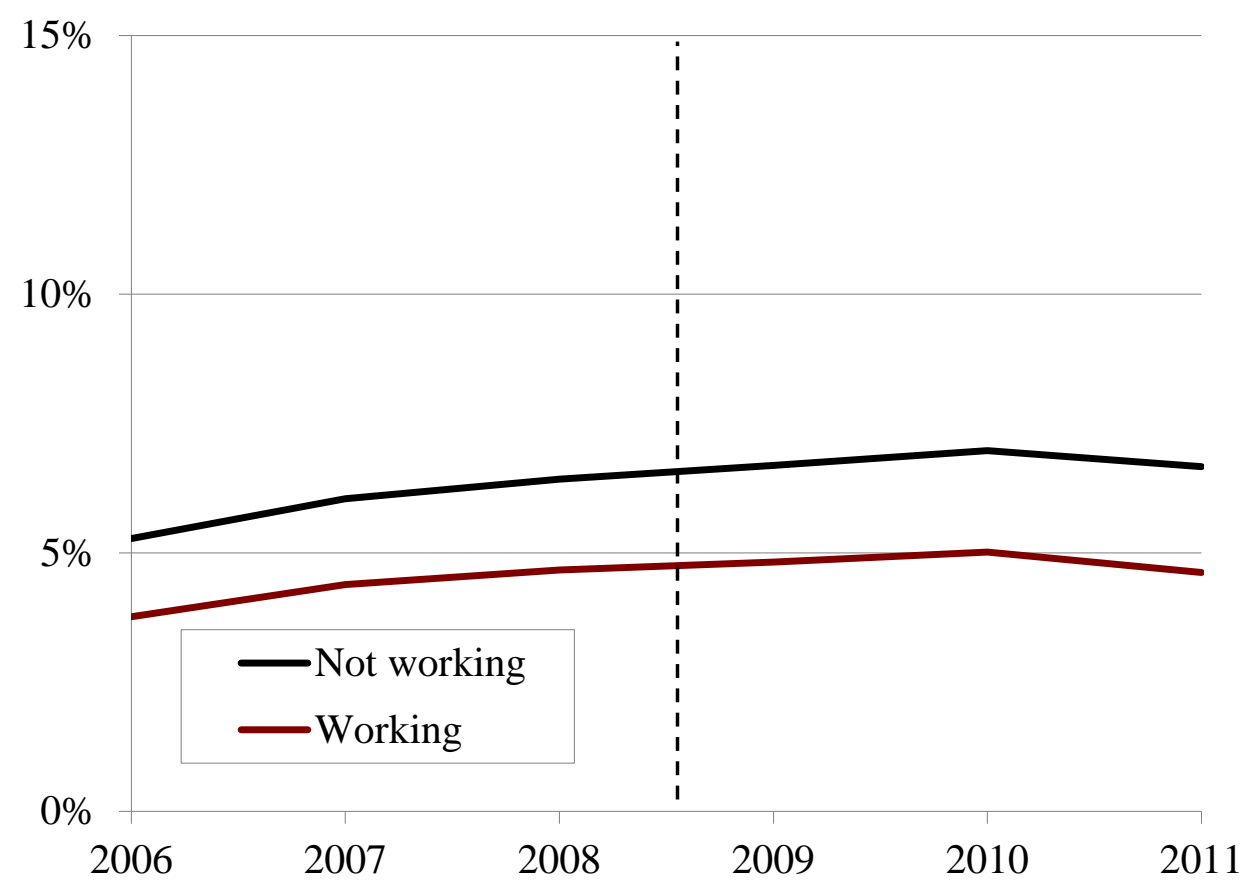

Source: Authors’ calculations using non-public microdata from Statistics Netherlands, 2006-2016. 
Figure 4a. Share Working for Men, by Age and DWB Eligibility

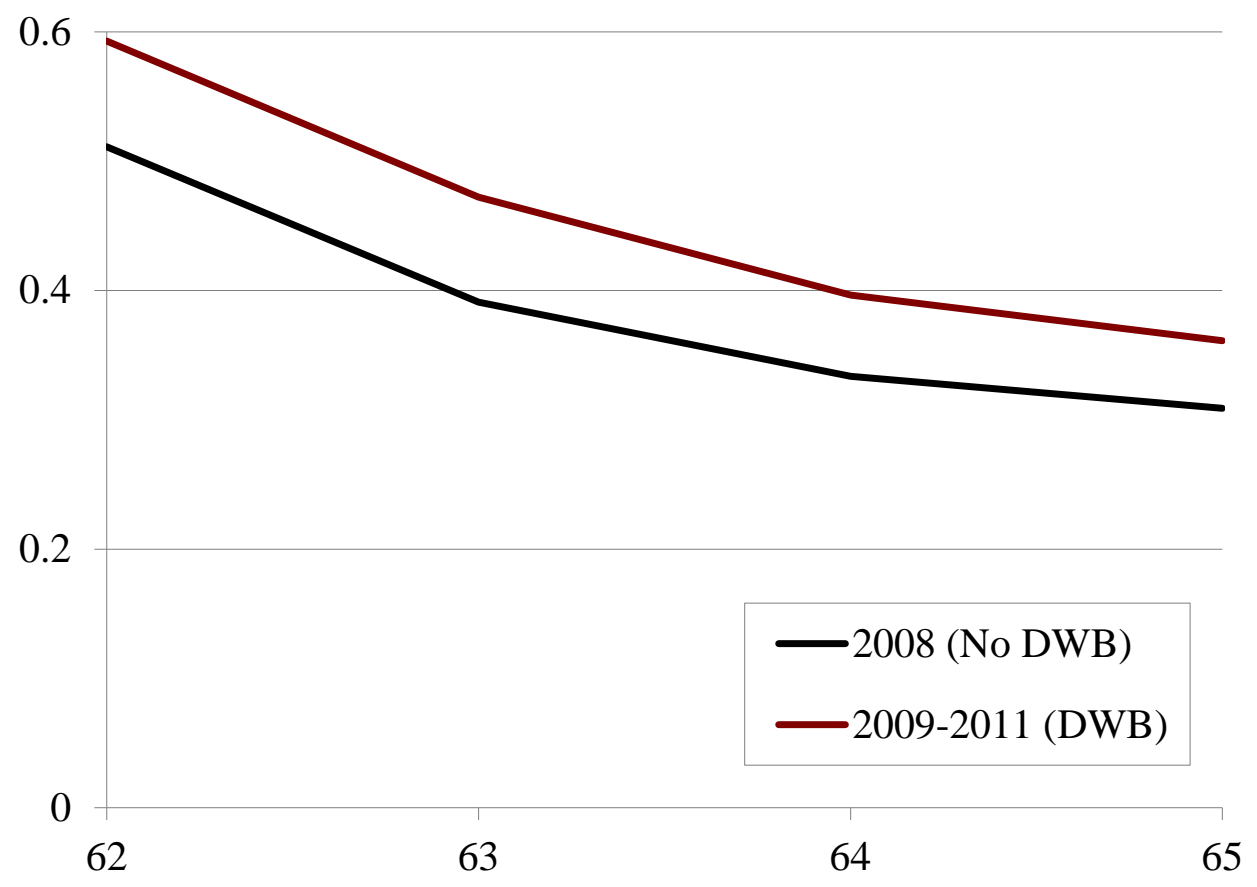

Figure 4b. Share Working for Women, by Age and DWB Eligibility

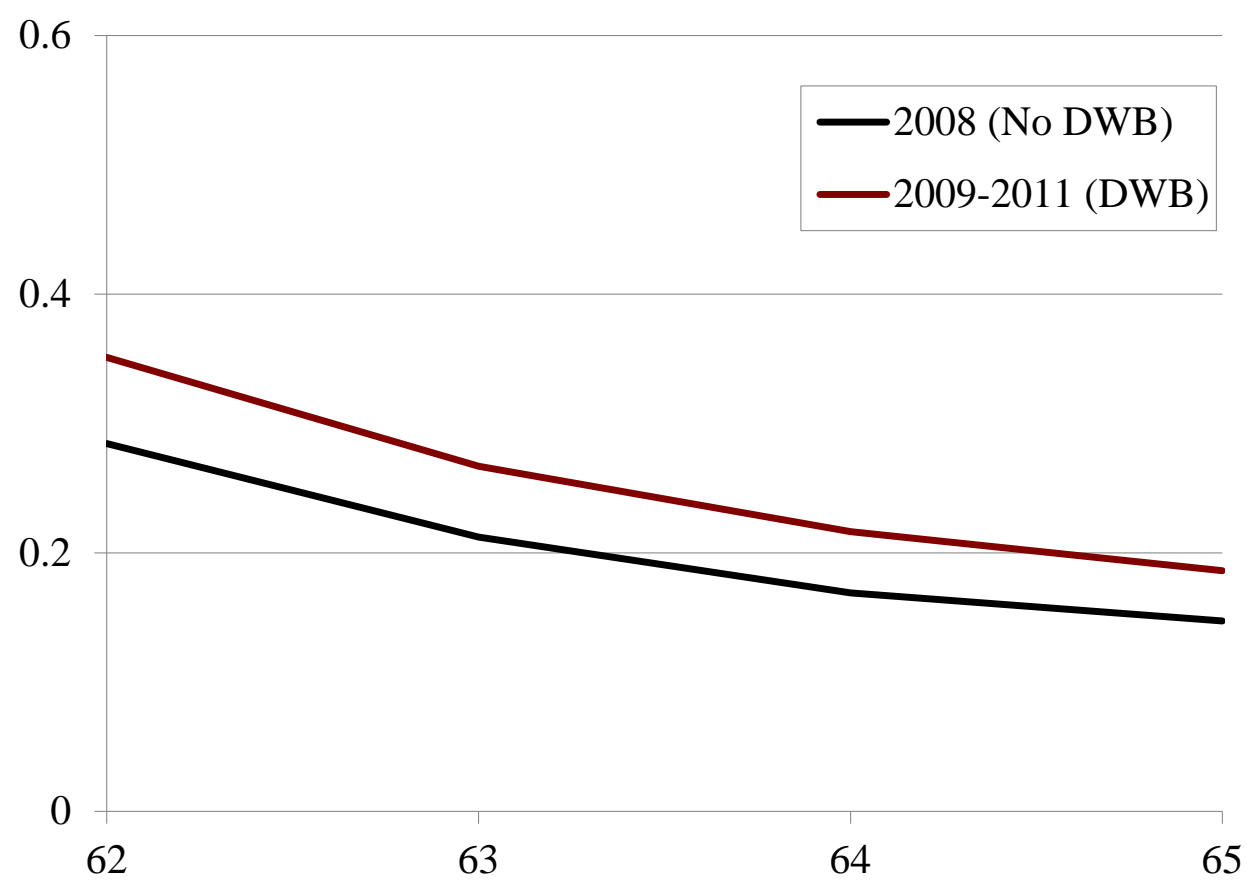

Source: Authors' calculations using non-public microdata from Statistics Netherlands, 2006-2011. 
Table 1. Structure of the "Doorwerkbonus" (DWB), by Age and Year

\begin{tabular}{|c|c|c|c|c|c|c|c|c|c|}
\hline \multirow[b]{3}{*}{ Birth cohort } & \multicolumn{9}{|c|}{ Year } \\
\hline & \multicolumn{3}{|c|}{2009} & \multicolumn{3}{|c|}{2010} & \multicolumn{3}{|c|}{2011} \\
\hline & Age & Bonus & Maximum & Age & Bonus & Maximum & Age & Bonus & Maximum \\
\hline 1939 & 70 & $1 \%$ & $€ 459$ & 71 & $1 \%$ & $€ 468$ & 72 & $1 \%$ & $€ 471$ \\
\hline 1940 & 69 & 1 & 459 & 70 & 1 & 468 & 71 & 1 & 471 \\
\hline 1941 & 68 & 1 & 459 & 69 & 1 & 468 & 70 & 1 & 471 \\
\hline 1942 & 67 & 1 & 459 & 68 & 1 & 468 & 69 & 1 & 471 \\
\hline 1943 & 66 & 2 & 918 & 67 & 1 & 468 & 68 & 1 & 471 \\
\hline 1944 & 65 & 2 & 918 & 66 & 2 & 936 & 67 & 1 & 471 \\
\hline 1945 & 64 & 10 & 4,592 & 65 & 2 & 936 & 66 & 2 & 942 \\
\hline 1946 & 63 & 7 & 3,214 & 64 & 10 & 4,679 & 65 & 2 & 942 \\
\hline 1947 & 62 & 5 & 2,296 & 63 & 7 & 3,276 & 64 & 10 & 4,708 \\
\hline 1948 & - & - & - & 62 & 5 & 2,340 & 63 & 7 & 3,295 \\
\hline 1949 & - & - & - & - & - & - & 62 & 5 & 2,354 \\
\hline 1950 & - & - & - & - & - & - & - & - & - \\
\hline Income cap & \multicolumn{3}{|c|}{$€ 54,776$} & \multicolumn{3}{|c|}{$€ 55,831$} & \multicolumn{3}{|c|}{$€ 56,280$} \\
\hline Income floor & \multicolumn{3}{|c|}{8,860} & \multicolumn{3}{|c|}{9,041} & \multicolumn{3}{|c|}{ 9,209 } \\
\hline
\end{tabular}

Source: Belastingdienst (Tax and Customs Administration - The Netherlands). 
Table 2. Overview of DWB Eligible Cohorts in Analysis Sample

\begin{tabular}{lcccccccccc|ccc}
\hline & $\mathbf{1 9 9 9}$ & $\mathbf{2 0 0 0}$ & $\mathbf{2 0 0 1}$ & $\mathbf{2 0 0 2}$ & $\mathbf{2 0 0 3}$ & $\mathbf{2 0 0 4}$ & $\mathbf{2 0 0 5}$ & $\mathbf{2 0 0 6}$ & $\mathbf{2 0 0 7}$ & $\mathbf{2 0 0 8}$ & $\mathbf{2 0 0 9}$ & $\mathbf{2 0 1 0}$ & $\mathbf{2 0 1 1}$ \\
\hline $\mathbf{1 9 4 3}$ & 56 & 57 & 58 & 59 & 60 & 61 & 62 & 63 & 64 & 65 & & & \\
$\mathbf{1 9 4 4}$ & 55 & 56 & 57 & 58 & 59 & 60 & 61 & 62 & 63 & 64 & & & \\
$\mathbf{1 9 4 5}$ & 54 & 55 & 56 & 57 & 58 & 59 & 60 & 61 & 62 & 63 & & & \\
$\mathbf{1 9 4 6}$ & 53 & 54 & 55 & 56 & 57 & 58 & 59 & 60 & 61 & 62 & 63 & 64 & 65 \\
$\mathbf{1 9 4 7}$ & 52 & 53 & 54 & 55 & 56 & 57 & 58 & 59 & 60 & 61 & 62 & 63 & 64 \\
$\mathbf{1 9 4 8}$ & 51 & 52 & 53 & 54 & 55 & 56 & 57 & 58 & 59 & 60 & 61 & 62 & 63 \\
$\mathbf{1 9 4 9}$ & 50 & 51 & 52 & 53 & 54 & 55 & 56 & 57 & 58 & 59 & 60 & 61 & 62 \\
$\mathbf{1 9 5 0}$ & 49 & 50 & 51 & 52 & 53 & 54 & 55 & 56 & 57 & 58 & 59 & 60 & 61 \\
$\mathbf{1 9 5 1}$ & 48 & 49 & 50 & 51 & 52 & 53 & 54 & 55 & 56 & 57 & 58 & 59 & 60 \\
$\mathbf{1 9 5 2}$ & 47 & 48 & 49 & 50 & 51 & 52 & 53 & 54 & 55 & 56 & 57 & 58 & 59 \\
$\mathbf{1 9 5 3}$ & 46 & 47 & 48 & 49 & 50 & 51 & 52 & 53 & 54 & 55 & 56 & 57 & 58 \\
$\mathbf{1 9 5 4}$ & 45 & 46 & 47 & 48 & 49 & 50 & 51 & 52 & 53 & 54 & 55 & 56 & 57 \\
\hline
\end{tabular}

Note: Shaded area indicates DWB eligibility.

Source: Belastingdienst (Tax and Customs Administration - The Netherlands). 
Table 3a. Sample Characteristics at Ages 62-65, Men

\begin{tabular}{|c|c|c|c|c|}
\hline & \multicolumn{2}{|c|}{ Eligible for DWB } & \multicolumn{2}{|c|}{ Not eligible for DWB } \\
\hline 5 year mortality risk & & $5.6 \%$ & & $6.1 \%$ \\
\hline 5 year depression risk & & 10.4 & & 10.0 \\
\hline 5 year diabetes risk & & 8.7 & & 7.2 \\
\hline Working & & 48.1 & & 39.1 \\
\hline & Working & Not working & Working & Not working \\
\hline 5 year mortality risk & $3.8 \%$ & $7.3 \%$ & $4.2 \%$ & $7.3 \%$ \\
\hline 5 year depression risk & 8.3 & 12.4 & 7.9 & 11.3 \\
\hline 5 year diabetes risk & 8.0 & 9.3 & 6.7 & 7.5 \\
\hline Married & 80.7 & 74.0 & 82.5 & 77.6 \\
\hline Widowed & 2.9 & 3.9 & 2.9 & 4.0 \\
\hline Divorced & 10.6 & 12.5 & 9.7 & 10.7 \\
\hline Pension recipient & 54.3 & 75.5 & 56.2 & 73.6 \\
\hline UI & 4.0 & 5.1 & 4.3 & 7.7 \\
\hline DI & 11.0 & 30.8 & 13.7 & 32.1 \\
\hline Welfare & 0.5 & 4.9 & 0.5 & 4.6 \\
\hline Other social benefits & 4.2 & 10.7 & 4.7 & 11.2 \\
\hline Gross income in 1999 & 30,700 Euro & 25,395 Euro & 29,519 Euro & 23,818 Euro \\
\hline
\end{tabular}

Notes: Sample contains men born between 1943 and 1949 observed at ages 62 through 65. For cohorts born between 1943 and 1945, observations after 2009 are not included.

Source: Authors' calculations using non-public microdata from Statistics Netherlands, 2006-2016. 
Table 3b. Sample Characteristics at Ages 62-65, Women

\begin{tabular}{|c|c|c|c|c|}
\hline & \multicolumn{2}{|c|}{ Eligible for DWB } & \multicolumn{2}{|c|}{ Not eligible for DWB } \\
\hline 5 year mortality risk & & $3.8 \%$ & & $3.9 \%$ \\
\hline 5 year depression risk & & 16.6 & & 16.9 \\
\hline 5 year diabetes risk & & 6.1 & & 5.7 \\
\hline Working & & 27.3 & & 20.3 \\
\hline & Working & Not working & Working & Not working \\
\hline 5 year mortality risk & $2.4 \%$ & $4.4 \%$ & $2.3 \%$ & $4.3 \%$ \\
\hline 5 year depression risk & 12.6 & 18.1 & 12.4 & 18.0 \\
\hline 5 year diabetes risk & 4.7 & 6.6 & 4.4 & 6.0 \\
\hline Married & 66.3 & 72.9 & 66.8 & 72.8 \\
\hline Widowed & 8.4 & 10.5 & 9.7 & 11.6 \\
\hline Divorced & 18.8 & 11.6 & 17.8 & 11.1 \\
\hline Pension recipient & 48.7 & 48.2 & 50.2 & 43.3 \\
\hline UI & 2.9 & 1.8 & 2.9 & 2.7 \\
\hline DI & 5.9 & 17.0 & 6.7 & 17.0 \\
\hline Welfare & 1.0 & 6.2 & 1.1 & 6.3 \\
\hline Other social benefits & 1.8 & 2.9 & 2.0 & 3.2 \\
\hline Gross income in 1999 & 12,383 Euro & 5,377 Euro & 10,975 Euro & 4,308 Euro \\
\hline
\end{tabular}

Notes: Sample contains women born between 1943 and 1949 observed at ages 62 through 65 . For cohorts born between 1943 and 1945, observations after 2009 are not included.

Source: Authors’ calculations using non-public microdata from Statistics Netherlands, 2006-2016. 
Table 4a. OLS Estimates of Mortality Risk on Working Status, 1999-2011

\begin{tabular}{|c|c|c|c|c|c|c|}
\hline & \multicolumn{3}{|c|}{ Men } & \multicolumn{3}{|c|}{ Women } \\
\hline & $(1)$ & $(2)$ & $(3)$ & $(4)$ & $(5)$ & $(6)$ \\
\hline Working $(0 / 1)$ & $\begin{array}{l}-0.024^{* * *} \\
(0.001)\end{array}$ & $\begin{array}{l}-0.024^{* * *} \\
(0.001)\end{array}$ & $\begin{array}{l}-0.020^{* * *} \\
(0.000)\end{array}$ & $\begin{array}{l}-0.014^{* * *} \\
(0.000)\end{array}$ & $\begin{array}{l}-0.013^{* * *} \\
(0.000)\end{array}$ & $\begin{array}{l}-0.008 * * * \\
(0.000)\end{array}$ \\
\hline Age fixed effects & Yes & Yes & Yes & Yes & Yes & Yes \\
\hline Industry fixed effects & No & Yes & Yes & No & Yes & Yes \\
\hline Benefit controls & No & No & Yes & No & No & Yes \\
\hline 5-year mortality non-working 2008 & $7.5 \%$ & $7.5 \%$ & $7.5 \%$ & $4.4 \%$ & $4.4 \%$ & $4.4 \%$ \\
\hline 5-year mortality working 2008 & 4.2 & 4.2 & 4.2 & 2.3 & 2.3 & 2.3 \\
\hline Observations & $16,371,962$ & $16,371,962$ & $16,371,962$ & $15,927,915$ & $15,927,915$ & $15,927,915$ \\
\hline R2 & 0.016 & 0.019 & 0.040 & 0.007 & 0.007 & 0.010 \\
\hline
\end{tabular}

Notes: Sample contains men and women born between 1943 and 1954 observed from 1999 through 2011. For cohorts born between 1943 and 1945, observations after 2009 are not included. All models include controls for marital status, income in 1999, an indicator for DWB eligible cohort (cohorts 19461949), an indicator for cohorts born in 1950 or later, year fixed effects, and age fixed effects. Benefit controls include indicators for whether a person receives a pension, welfare, UI, DI or other social benefits. Robust standard errors clustered at the birth cohort - year level in parentheses. $* * *$ p $<0.01$.

Source: Authors’ calculations using non-public microdata from Statistics Netherlands, 1999-2016. 
Table 4b. 2SLS Estimates of the effect of Working Status on the Five Year Mortality Risk, 1999-2011

\begin{tabular}{|c|c|c|c|c|c|c|}
\hline & \multicolumn{3}{|c|}{ Men } & \multicolumn{3}{|c|}{ Women } \\
\hline & $(1)$ & $(2)$ & (3) & $(4)$ & (5) & (6) \\
\hline \multirow[t]{2}{*}{ Working $g_{i t}$} & $-0.023 * * *$ & $-0.024 * * *$ & $-0.033 * *$ & 0.005 & 0.005 & 0.018 \\
\hline & $(0.008)$ & $(0.008)$ & $(0.013)$ & $(0.040)$ & $(0.043)$ & -0.048 \\
\hline Observations & $16,371,962$ & $16,371,962$ & $16,371,962$ & $15,927,915$ & $15,927,915$ & $15,927,915$ \\
\hline Age fixed effects & Yes & Yes & Yes & Yes & Yes & Yes \\
\hline Industry fixed effects & No & Yes & Yes & No & Yes & Yes \\
\hline Benefit controls & No & No & Yes & No & No & Yes \\
\hline 5-year mortality non-working 2008 & $7.5 \%$ & $7.5 \%$ & $7.5 \%$ & $4.4 \%$ & $4.4 \%$ & $4.4 \%$ \\
\hline 5-year mortality working 2008 & 4.2 & 4.2 & 4.2 & 2.3 & 2.3 & 2.3 \\
\hline \multicolumn{7}{|l|}{ First stage } \\
\hline F Statistic & 15 & 15 & 19.84 & 4 & 4 & 6 \\
\hline DWB coefficient & $\begin{array}{l}0.035^{* * *} \\
(0.009)\end{array}$ & $\begin{array}{c}0.034^{* * *} \\
(0.009)\end{array}$ & $\begin{array}{l}0.029 * * * \\
(0.006)\end{array}$ & $\begin{array}{c}0.011^{*} \\
(0.006)\end{array}$ & $\begin{array}{r}0.011 \\
(0.006)\end{array}$ & $\begin{array}{c}0.014 * * \\
(0.006)\end{array}$ \\
\hline
\end{tabular}

Notes: Sample contains men and women born between 1943 and 1954 observed from 1999 through 2011. For cohorts born between 1943 and 1945 ,

observations after 2009 are not included. DWB instrument is 1 after 2009 for cohorts born between 1945-1949. All models include controls for marital status, indicator for DWB eligible cohorts, indicator for younger ineligible cohorts, income in 1999, year and age fixed effects. Benefit controls include indicators for whether a person receives a pension, welfare, UI, DI or other social benefits. The table reports the Kleibergen-Paap F statistic. Robust standard errors clustered at the birth cohort - year level in parentheses. $*<0.01 ; * * \mathrm{p}<0.05$; $* * * \mathrm{p}<0.01$.

Source: Authors' calculations using non-public microdata from Statistics Netherlands, 1999-2016. 
Table 4c. 2SLS Estimates of Mortality Risk on Working Status, Robustness Tests

\begin{tabular}{lccc}
\hline & \multicolumn{3}{c}{ Men } \\
\cline { 2 - 4 } & $\begin{array}{c}\text { Preferred } \\
\text { estimate }\end{array}$ & $\begin{array}{c}\text { Working at } \\
\text { age 55 }\end{array}$ & $\begin{array}{c}\text { Controlling for } \\
\text { income in 1999 }\end{array}$ \\
\cline { 2 - 5 } Working & $-0.024^{* * *}$ & $-0.025^{* * *}$ & $-0.024^{* * *}$ \\
& $(0.008)$ & $(0.006)$ & $(0.008)$ \\
Observations & $16,371,962$ & $6,542,299$ & $16,371,962$ \\
& & & \\
Age fixed effects & Yes & Yes & Yes \\
Industry fixed effects & Yes & Yes & Yes \\
Benefit controls & No & No & No \\
First stage & & & 15 \\
$\quad$ F statistic & 15 & 28 & 15 \\
DWB coefficient & $0.034^{* * *}$ & $0.058^{* * *}$ & $0.034^{* * *}$ \\
& $(0.009)$ & $(0.011)$ & $(0.009)$ \\
\hline
\end{tabular}

Notes: Other controls include for marital status, indicator for DWB eligible cohorts, indicator for younger ineligible cohorts, income in 1999, year and age fixed effects. The specifications in column 1 and 2 also control for income in 1999. The table reports the Kleibergen-Paap F statistic. Robust standard errors clustered at the birth cohort - year level in parentheses. ${ }^{* * *} \mathrm{p}<0.01$.

Source: Authors’ calculations using non-public microdata from Statistics Netherlands, 1999-2016. 
Table 5a. Linear Regression Estimates of Depression Risk on Working Status, 2006-2011

\begin{tabular}{|c|c|c|c|c|c|c|}
\hline & \multicolumn{3}{|c|}{ Men } & \multicolumn{3}{|c|}{ Women } \\
\hline & $(1)$ & $(2)$ & (3) & $(4)$ & $(5)$ & (6) \\
\hline Working $(0 / 1)$ & $\begin{array}{l}-0.051^{* * *} \\
(0.004)\end{array}$ & $\begin{array}{l}-0.055^{* * * *} \\
(0.004)\end{array}$ & $\begin{array}{l}-0.019 * * * \\
(0.001)\end{array}$ & $\begin{array}{l}-0.063^{* * *} \\
(0.004)\end{array}$ & $\begin{array}{l}-0.063^{* * *} \\
(0.004)\end{array}$ & $\begin{array}{l}-0.019 * * * \\
(0.001)\end{array}$ \\
\hline Age fixed effects & Yes & Yes & Yes & Yes & Yes & Yes \\
\hline Industry fixed effects & No & Yes & Yes & No & Yes & Yes \\
\hline Benefit controls & No & No & Yes & No & No & Yes \\
\hline 5-year depression non-working 2008 & $12 \%$ & $12 \%$ & $12 \%$ & $18 \%$ & $18 \%$ & $18 \%$ \\
\hline 5-year depression working 2008 & 8 & 8 & 8 & 13 & 13 & 13 \\
\hline Observations & $6,953,084$ & $6,953,084$ & $6,953,084$ & $6,811,939$ & 6,811,939 & $6,811,939$ \\
\hline $\mathrm{R} 2$ & 0.016 & 0.019 & 0.04 & 0.016 & 0.017 & 0.038 \\
\hline
\end{tabular}

Notes: The outcome is an indicator for whether the person was on anti-depressants in the next five years. Sample contains men and women born between 1943 and 1954, observed from 2006 through 2011. For cohorts born between 1943 and 1945, observations after 2009 are not included. All models include controls for marital status, indicator for DWB eligible cohorts, indicator for younger ineligible cohorts, income in 1999, year and age fixed effects. Benefit controls include indicators for whether a person receives a pension, welfare, UI, DI or other social benefits. Robust standard errors clustered at the birth cohort - year level in parentheses. $* * * \mathrm{p}<0.01$.

Source: Authors’ calculations using non-public microdata from Statistics Netherlands, 2006-2016. 
Table 5b. Two-Stage-Least-Squares Estimates of Depression Risk on Working Status, 2006-2011

\begin{tabular}{|c|c|c|c|c|c|c|}
\hline & \multicolumn{3}{|c|}{ Men } & \multicolumn{3}{|c|}{ Women } \\
\hline & $(1)$ & $(2)$ & (3) & (4) & (5) & (6) \\
\hline Workıng $_{i t}$ & $\begin{array}{r}0.048 \\
(0.030) \\
\end{array}$ & $\begin{array}{r}0.043 \\
(0.030) \\
\end{array}$ & $\begin{array}{r}0.070 \\
(0.049) \\
\end{array}$ & $\begin{array}{r}0.613 \\
(2.590) \\
\end{array}$ & $\begin{array}{r}0.259 \\
(0.716) \\
\end{array}$ & $\begin{array}{r}1.780 \\
(27.517) \\
\end{array}$ \\
\hline Observations & $6,953,084$ & $6,953,084$ & $6,953,084$ & $6,811,939$ & $6,811,939$ & $6,811,939$ \\
\hline Age fixed effects & Yes & Yes & Yes & Yes & Yes & Yes \\
\hline Industry fixed effects & No & Yes & Yes & No & Yes & Yes \\
\hline Benefit controls & No & No & Yes & No & No & Yes \\
\hline 5-year depression non-working 2008 & $12 \%$ & $12 \%$ & $12 \%$ & $18 \%$ & $18 \%$ & $18 \%$ \\
\hline 5-year depression working 2008 & 8 & 8 & 8 & 13 & 13 & 13 \\
\hline \multicolumn{7}{|l|}{ First stage } \\
\hline F statistic & 12 & 11 & 10 & 0.04 & 0.4 & 0 \\
\hline DWB coefficient & $\begin{array}{l}0.034^{* * * *} \\
(0.010)\end{array}$ & $\begin{array}{l}0.033^{* * *} \\
(0.010)\end{array}$ & $\begin{array}{l}0.022^{* * *} \\
(0.007)\end{array}$ & $\begin{array}{r}0.001 \\
(0.005)\end{array}$ & $\begin{array}{r}0.003 \\
(0.005)\end{array}$ & $\begin{array}{r}0.000 \\
(0.005)\end{array}$ \\
\hline
\end{tabular}

Notes: The outcome is an indicator for whether the person was on anti-depressants in the next five years. Sample contains men and women born between 1943 and 1954, observed from 2006 through 2011. For cohorts born between 1943 and 1945, observations after 2009 are not included. All models include controls for marital status, indicator for DWB eligible cohorts, indicator for younger ineligible cohorts, income in 1999, year and age fixed effects. Benefit controls include indicators for whether a person receives a pension, welfare, UI, DI or other social benefits. The table reports the Kleibergen-Paap F statistic. Robust standard errors clustered at the birth cohort - year level in parentheses. $* * * \mathrm{p}<0.01$.

Source: Authors’ calculations using non-public microdata from Statistics Netherlands, 2006-2016. 
Table 6a. Linear Regression Estimates of Diabetes Risk on Working Status, 2006-2011

\begin{tabular}{|c|c|c|c|c|c|c|}
\hline & \multicolumn{3}{|c|}{ Men } & \multicolumn{3}{|c|}{ Women } \\
\hline & $(1)$ & $(2)$ & (3) & $(4)$ & $(5)$ & $(6)$ \\
\hline Working $(0 / 1)$ & $\begin{array}{l}-0.006 * * * \\
(0.001)\end{array}$ & $\begin{array}{l}-0.006^{* * *} \\
(0.001)\end{array}$ & $\begin{array}{l}-0.002^{* * *} \\
(0.000)\end{array}$ & $\begin{array}{l}-0.007^{* * *} \\
(0.001)\end{array}$ & $\begin{array}{l}-0.006^{* * *} \\
(0.000)\end{array}$ & $\begin{array}{l}-0.003^{* * *} \\
(0.000)\end{array}$ \\
\hline Age fixed effects & Yes & Yes & Yes & Yes & Yes & Yes \\
\hline Industry fixed effects & No & Yes & Yes & No & Yes & Yes \\
\hline Benefit controls & No & No & Yes & No & No & Yes \\
\hline 5-year diabetes non-working 2008 & $7 \%$ & $7 \%$ & $7 \%$ & $6 \%$ & $6 \%$ & $6 \%$ \\
\hline 5-year diabetes working 2008 & 6 & 6 & 6 & 4 & 4 & 4 \\
\hline Observations & $6,281,092$ & $6,281,092$ & $6,281,092$ & $6,312,257$ & $6,312,257$ & $6,312,257$ \\
\hline $\mathrm{R} 2$ & 0.007 & 0.008 & 0.009 & 0.006 & 0.007 & 0.008 \\
\hline
\end{tabular}

Notes: The outcome is an indicator for whether the person was on diabetes medication in the next five years. Sample contains men and women born between 1943 and 1954, who did not have any diabetes prescriptions at baseline, observed from 2006 through 2011. For cohorts born between 1943 and 1945,

observations after 2009 are not included. All models include controls for marital status, indicator for DWB eligible cohorts, indicator for younger ineligible cohorts, income in 1999, year and age fixed effects. Benefit controls include indicators for whether a person receives a pension, welfare, UI, DI or other social benefits. Robust standard errors clustered at the birth cohort - year level in parentheses. ${ }^{* * *} \mathrm{p}<0.01$.

Source: Authors' calculations using non-public microdata from Statistics Netherlands, 2006-2016. 
Table 6b. Two-Stage-Least-Squares Estimates of Diabetes Risk on Working Status, 2006-2011

\begin{tabular}{|c|c|c|c|c|c|c|}
\hline & \multicolumn{3}{|c|}{ Men } & \multicolumn{3}{|c|}{ Women } \\
\hline & $(1)$ & $(2)$ & (3) & (4) & $(5)$ & $(6)$ \\
\hline \multirow[t]{2}{*}{ Workung } & 0.013 & 0.014 & 0.015 & 0.064 & 0.410 & 1.546 \\
\hline & $(0.014)$ & $(0.014)$ & $(0.022)$ & $(1.285)$ & $(0.530)$ & $(7.508)$ \\
\hline Observations & $6,281,092$ & $6,281,092$ & $6,281,092$ & $6,312,257$ & $6,312,257$ & $6,312,257$ \\
\hline Age fixed effects & Yes & Yes & Yes & Yes & Yes & Yes \\
\hline Industry fixed effects & No & Yes & Yes & No & Yes & Yes \\
\hline Benefit controls & No & No & Yes & No & No & Yes \\
\hline 5-year diabetes non-working 2008 & $7 \%$ & $7 \%$ & $7 \%$ & $6 \%$ & $6 \%$ & $6 \%$ \\
\hline 5-year diabetes working 2008 & 6 & 6 & 6 & 4 & 4 & 4 \\
\hline \multicolumn{7}{|l|}{ First stage } \\
\hline F statistic & 10 & 9 & 10 & 0 & 1 & 0 \\
\hline DWB coefficient & $\begin{array}{l}0.034^{* * *} \\
(0.011)\end{array}$ & $\begin{array}{l}0.033^{* * * *} \\
(0.011)\end{array}$ & $\begin{array}{l}0.022^{* * * *} \\
(0.007)\end{array}$ & $\begin{array}{r}0.002 \\
(0.005)\end{array}$ & $\begin{array}{r}0.004 \\
(0.005)\end{array}$ & $\begin{array}{r}0.001 \\
(0.005)\end{array}$ \\
\hline
\end{tabular}

Notes: The outcome is an indicator for whether the person was on diabetes medication in the next five years. Sample contains men and women born between 1943 and 1954, who did not have any diabetes prescriptions at baseline, observed from 2006 through 2011. For cohorts born between 1943 and 1945, observations after 2009 are not included. All models include controls for marital status, indicator for DWB eligible cohorts, indicator for younger ineligible cohorts, income in 1999, year and age fixed effects. Benefit controls include indicators for whether a person receives a pension, welfare, UI, DI or other social benefits. The table reports the Kleibergen-Paap F statistic. Robust standard errors clustered at the birth cohort - year level in parentheses. $*<0.01 ; * * ~ p<0.05$; $* * * \mathrm{p}<0.01$.

Source: Authors’ calculations using non-public microdata from Statistics Netherlands, 2006-2016. 


\section{Appendix}

Figure A1. Unemployment Rate Ages 45-70, by Gender

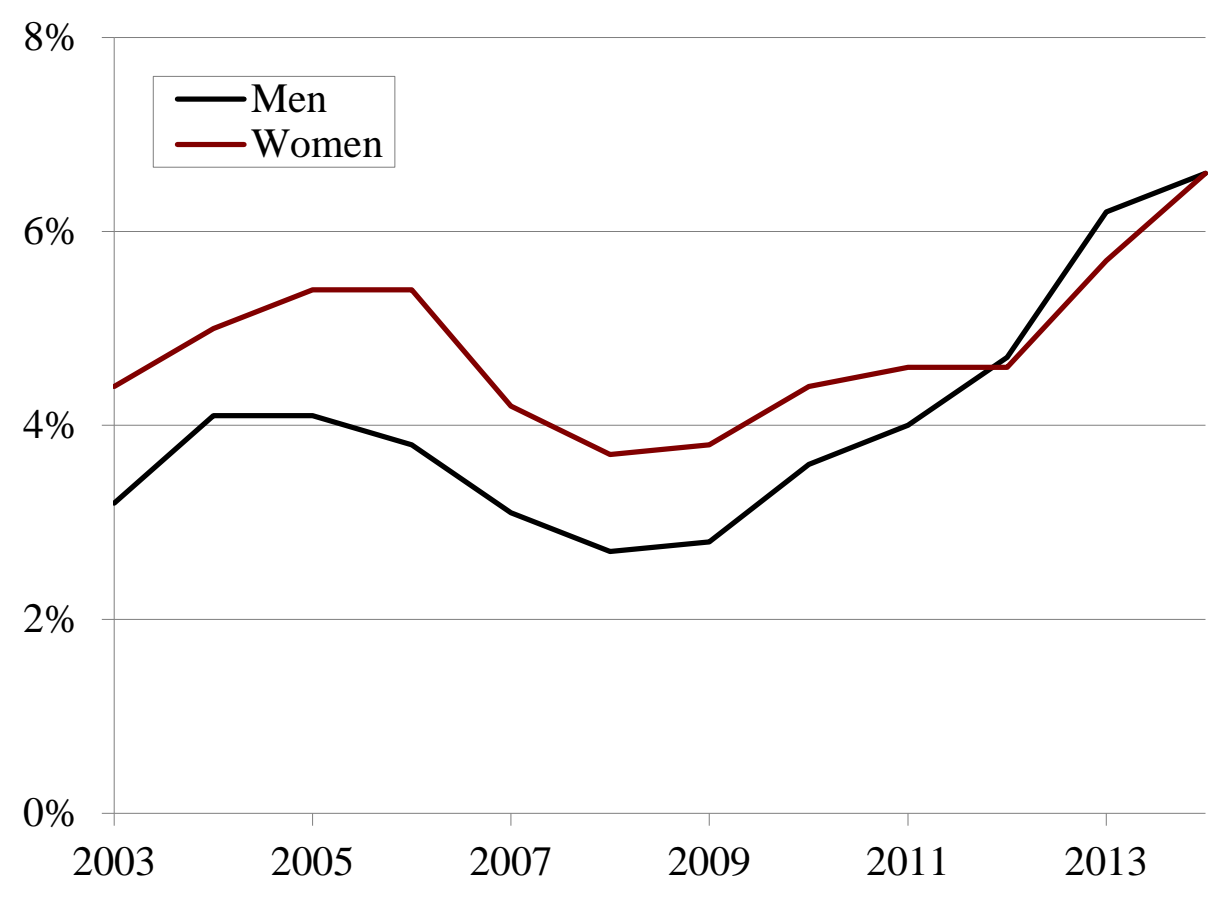

Source: Statistics Netherlands, Statline, 2002-2014. 
Table A1a. Full OLS Estimates of Mortality Risk on Working Status - Men, 1999-2011

\begin{tabular}{lccc}
\hline & $(1)$ & $(2)$ & $(3)$ \\
\hline Working & $-0.024^{* * *}$ & $-0.024^{* * *}$ & $-0.020^{* * *}$ \\
Married & $(0.001)$ & $(0.001)$ & $(0.000)$ \\
& $-0.023^{* * *}$ & $-0.022^{* * *}$ & $-0.023^{* * *}$ \\
Widowed & $(0.001)$ & $(0.001)$ & $(0.001)$ \\
& $-0.006^{* * *}$ & $-0.006^{* * *}$ & $-0.002^{* *}$ \\
Divorced & $(0.001)$ & $(0.001)$ & $(0.001)$ \\
& $-0.003^{* * *}$ & $-0.002^{* * *}$ & -0.004 \\
Pension & $(0.000)$ & $(0.000)$ & $(0.000)$ \\
& & & $-0.010^{* * *}$ \\
UI & & & $(0.001)$ \\
& & & -0.010 \\
Welfare & & & $(0.000)$ \\
& & & $0.022^{* * *}$ \\
DI & & & $0.001)$ \\
& & & $0.028^{* * *}$ \\
Other social benefits & & & $0.001)$ \\
& & & $0.004^{* * *}$ \\
Constant & & $0.052^{* * *}$ & $0.047^{* * *}$ \\
& & & $(0.001)$ \\
Age fixed effects & & Yes & Yes \\
Industry fixed effects & Yes & Yos & Yes \\
Benefit controls & No & No & Yes \\
Observations & $16,371,962$ & $16,371,962$ & $16,371,962$ \\
& 0.016 & 0.019 & 0.040 \\
\hline & & & \\
\hline
\end{tabular}

Notes: Sample contains men born between 1943 and 1954 observed from 1999 through 2011. For cohorts born between 1943 and 1945, observations after 2009 are not included. All models include controls for income in 1999, an indicator for DWB eligible cohort (cohorts 1946-1949), an indicator for cohorts born in 1950 or later, year fixed effects, and age fixed effects. Robust standard errors clustered at the birth cohort - year level in parentheses. *** $\mathrm{p}<0.01$.

Source: Authors’ calculations using non-public microdata from Statistics Netherlands, 1999-2016. 
Table A1b. Full OLS Estimates of Mortality Risk on Working Status - Women, 1999-2011

\begin{tabular}{|c|c|c|c|}
\hline & (1) & $(2)$ & (3) \\
\hline Working & $\begin{array}{l}-0.014^{* * *} \\
(0.000)\end{array}$ & $\begin{array}{l}-0.013^{* * *} \\
(0.000)\end{array}$ & $\begin{array}{l}-0.008 * * * \\
(0.000)\end{array}$ \\
\hline Married & $\begin{array}{l}-0.020^{* * *} \\
(0.001)\end{array}$ & $\begin{array}{l}-0.020^{* * *} \\
(0.001)\end{array}$ & $\begin{array}{l}-0.014 * * * \\
(0.001)\end{array}$ \\
\hline Widowed & $\begin{array}{l}-0.010^{* * *} \\
(0.000)\end{array}$ & $\begin{array}{l}-0.010^{* * *} \\
(0.000)\end{array}$ & $\begin{array}{l}-0.001 * * * \\
(0.000)\end{array}$ \\
\hline Divorced & $\begin{array}{l}-0.007^{* * *} \\
(0.000)\end{array}$ & $\begin{array}{l}-0.007^{* * *} \\
(0.000)\end{array}$ & $\begin{array}{l}-0.005^{* * *} \\
(0.000)\end{array}$ \\
\hline Pension & & & $\begin{array}{l}-0.005 * * * \\
(0.000)\end{array}$ \\
\hline UI & & & $\begin{array}{l}-0.011^{* * *} \\
(0.000)\end{array}$ \\
\hline Welfare & & & $\begin{array}{l}0.012^{* * *} \\
(0.000)\end{array}$ \\
\hline DI & & & $\begin{array}{l}0.021^{* * * *} \\
(0.000)\end{array}$ \\
\hline Other social benefits & & & $\begin{array}{l}0.020^{* * * *} \\
(0.001)\end{array}$ \\
\hline Constant & $\begin{array}{l}0.037 * * * \\
(0.001)\end{array}$ & $\begin{array}{l}0.035^{* * *} \\
(0.001)\end{array}$ & $\begin{array}{l}0.025^{* * *} \\
(0.001)\end{array}$ \\
\hline Age fixed effects & Yes & Yes & Yes \\
\hline Industry fixed effects & No & Yes & Yes \\
\hline Benefit controls & No & No & Yes \\
\hline Observations & $\begin{array}{c}15,927,915 \\
0.007\end{array}$ & $\begin{array}{c}15,927,915 \\
0.007\end{array}$ & $\begin{array}{c}15,927,915 \\
0.010\end{array}$ \\
\hline
\end{tabular}

Notes: Sample contains women born between 1943 and 1954 observed from 1999 through 2011. For cohorts born between 1943 and 1945, observations after 2009 are not included. All models include controls for income in 1999, an indicator for DWB eligible cohort (cohorts 1946-1949), an indicator for cohorts born in 1950 or later, year fixed effects, and age fixed effects. Robust standard errors clustered at the birth cohort - year level in parentheses. ${ }^{* * *}$ $\mathrm{p}<0.01$.

Source: Authors’ calculations using non-public microdata from Statistics Netherlands, 1999-2016. 
Table A2a. Full 2SLS Estimates of the effect of Working Status on the Five Year Mortality Risk Men, 1999-2011

\begin{tabular}{|c|c|c|c|}
\hline & (1) & (2) & (3) \\
\hline Working & $\begin{array}{l}-0.023^{* * *} \\
(0.008)\end{array}$ & $\begin{array}{l}-0.024^{* * *} \\
(0.008)\end{array}$ & $\begin{array}{l}-0.033^{* *} \\
(0.013)\end{array}$ \\
\hline Married & $\begin{array}{l}-0.023^{* * *} \\
(0.001)\end{array}$ & $\begin{array}{l}-0.022^{* * *} \\
(0.001)\end{array}$ & $\begin{array}{l}-0.022^{* * *} \\
(0.001)\end{array}$ \\
\hline Widowed & $\begin{array}{l}-0.006 * * * \\
(0.001)\end{array}$ & $\begin{array}{l}-0.006^{* * *} \\
(0.001)\end{array}$ & $\begin{array}{r}-0.001 \\
(0.002)\end{array}$ \\
\hline Divorced & $\begin{array}{l}-0.003^{* * *} \\
(0.000)\end{array}$ & $\begin{array}{l}-0.002^{* * *} \\
(0.000)\end{array}$ & $\begin{array}{l}-0.004^{* * *} \\
(0.000)\end{array}$ \\
\hline Pension & & & $\begin{array}{l}-0.013^{* * *} \\
(0.003)\end{array}$ \\
\hline UI & & & $\begin{array}{l}-0.012 * * * \\
(0.002)\end{array}$ \\
\hline Welfare & & & $\begin{array}{l}0.020^{* * * *} \\
(0.003)\end{array}$ \\
\hline DI & & & $\begin{array}{l}0.026^{* * * *} \\
(0.002)\end{array}$ \\
\hline Other social benefits & & & $\begin{array}{r}0.003 \\
(0.002)\end{array}$ \\
\hline Age fixed effects & Yes & Yes & Yes \\
\hline Industry fixed effects & No & Yes & Yes \\
\hline Benefit controls & No & No & Yes \\
\hline Observations & $16,371,962$ & $16,371,962$ & $16,371,962$ \\
\hline \multicolumn{4}{|l|}{ First stage } \\
\hline F statistic & 15 & 15 & 20 \\
\hline DWB coefficient & $\begin{array}{l}0.035^{* * * *} \\
(0.009)\end{array}$ & $\begin{array}{l}0.034^{* * *} \\
(0.009)\end{array}$ & $\begin{array}{l}0.029 * * * \\
(0.006)\end{array}$ \\
\hline
\end{tabular}

Notes: Sample contains men born between 1943 and 1954 observed from 1999 through 2011. For cohorts born between 1943 and 1945, observations after 2009 are not included. DWB instrument is 1 after 2009 for cohorts born between 1945-1949. All models include controls for indicator for DWB eligible cohorts, indicator for younger ineligible cohorts, income in 1999, year and age fixed effects. The table reports the Kleibergen-Paap F statistic. Robust standard errors clustered at the birth cohort - year level in parentheses. ${ }^{*}<0.01$; ${ }^{* *} \mathrm{p}<0.05 ;{ }^{* * *} \mathrm{p}<0.01$. Source: Authors' calculations using non-public microdata from Statistics Netherlands, 1999-2016. 
Table A2b. Full 2SLS Estimates of the effect of Working Status on the Five Year Mortality Risk Women, 1999-2011

\begin{tabular}{|c|c|c|c|}
\hline & (1) & (2) & (3) \\
\hline \multirow[t]{2}{*}{ Working } & 0.005 & 0.005 & 0.018 \\
\hline & $(0.040)$ & $(0.043)$ & $(0.047)$ \\
\hline \multirow[t]{2}{*}{ Married } & $-0.020 * * *$ & $-0.020 * * *$ & $-0.013^{* * *}$ \\
\hline & $(0.001)$ & $(0.001)$ & $(0.002)$ \\
\hline \multirow[t]{2}{*}{ Widowed } & -0.010 & -0.010 & -0.004 \\
\hline & 0.000 & 0.000 & $(0.004)$ \\
\hline \multirow[t]{2}{*}{ Divorced } & $-0.007 * * *$ & $-0.007 * * *$ & $-0.006^{* * *}$ \\
\hline & $(0.001)$ & $(0.001)$ & $(0.001)$ \\
\hline \multirow[t]{2}{*}{ Pension } & & & 0.000 \\
\hline & & & $(0.008)$ \\
\hline \multirow[t]{2}{*}{ UI } & & & -0.008 \\
\hline & & & $(0.006)$ \\
\hline \multirow[t]{2}{*}{ Welfare } & & & $0.015^{* * *}$ \\
\hline & & & $(0.005)$ \\
\hline \multirow[t]{2}{*}{ DI } & & & $0.025 * * *$ \\
\hline & & & $(0.007)$ \\
\hline \multirow[t]{2}{*}{ Other social benefits } & & & $0.022 * * *$ \\
\hline & & & $(0.004)$ \\
\hline Age fixed effects & Yes & Yes & Yes \\
\hline Industry fixed effects & No & Yes & Yes \\
\hline Benefit controls & No & No & Yes \\
\hline Observations & $15,927,915$ & $15,927,915$ & $15,927,915$ \\
\hline \multicolumn{4}{|l|}{ First stage } \\
\hline F Statistic & 4 & 4 & 6 \\
\hline \multirow[t]{2}{*}{ DWB coefficient } & -0.006 & -0.006 & -0.006 \\
\hline & $(0.004)$ & $(0.004)$ & $(0.004)$ \\
\hline
\end{tabular}

Notes: Sample contains women born between 1943 and 1954 observed from 1999 through 2011. For cohorts born between 1943 and 1945, observations after 2009 are not included. DWB instrument is 1 after 2009 for cohorts born between 1945-1949. All models include controls for indicator for DWB eligible cohorts, indicator for younger ineligible cohorts, income in 1999, year and age fixed effects. The table reports the Kleibergen-Paap F statistic. Robust standard errors clustered at the birth cohort - year level in parentheses. ${ }^{*}<0.01$; ${ }^{* *} \mathrm{p}<0.05 ; * * * \mathrm{p}<0.01$. Source: Authors' calculations using non-public microdata from Statistics Netherlands, 1999-2016. 
Table A3a. Full OLS Estimates of Depression Risk on Working Status- Men, 2006-2011

\begin{tabular}{lccc}
\hline & $(1)$ & $(2)$ & $(3)$ \\
\hline Working & $-0.051^{* * *}$ & $-0.055^{* * *}$ & $-0.019^{* * *}$ \\
Married & $(0.004)$ & $(0.004)$ & $(0.001)$ \\
& $0.012^{* * *}$ & $0.019 * * *$ & $0.010^{* * *}$ \\
Widowed & $(0.001)$ & $(0.001)$ & $(0.001)$ \\
& $0.024^{* * *}$ & $0.029^{* * *}$ & $0.018^{* * *}$ \\
Divorced & $(0.001)$ & $(0.001)$ & $(0.001)$ \\
& $0.038^{* * *}$ & $0.041^{* * *}$ & $0.027^{* * *}$ \\
Pension & $(0.000)$ & $(0.000)$ & $(0.001)$ \\
& & & $0.005^{* * *}$ \\
UI & & & $(0.001)$ \\
& & & $0.007 * * *$ \\
Welfare & & & $(0.001)$ \\
& & & $0.084 * * *$ \\
DI & & & $0.003)$ \\
& & & $0.136^{* * *}$ \\
Other social benefits & & $0.003)$ \\
& & & -0.001 \\
Constant & & $0.149 * * *$ & $0.102^{* * *}$ \\
& & & $(0.002)$ \\
Age fixed effects & & Yes & Yes \\
Industry fixed effects & Yes & Yes & Yes \\
Benefit controls & No & No & Yes \\
Observations & No & $6,953,084$ & $6,953,084$ \\
& $6,953,084$ & 0.019 & 0.040 \\
\hline
\end{tabular}

Notes: The outcome is an indicator for whether the person was on anti-depressants in the next five years. Sample contains men and women born between 1943 and 1954, observed from 2006 through 2011. For cohorts born between 1943 and 1945, observations after 2009 are not included. All models include controls indicator for DWB eligible cohorts, indicator for younger ineligible cohorts, income in 1999, year and age fixed effects. Robust standard errors clustered at the birth cohort - year level in parentheses. $* * * \mathrm{p}<0.01$.

Source: Authors’ calculations using non-public microdata from Statistics Netherlands, 2006-2016. 
Table A3b. Full OLS Estimates of Depression Risk on Working Status - Women, 2006-2011

\begin{tabular}{|c|c|c|c|}
\hline & (1) & (2) & (3) \\
\hline Working & $\begin{array}{l}-0.063 * * * \\
(0.000)\end{array}$ & $\begin{array}{l}-0.063 * * * \\
(0.000)\end{array}$ & $\begin{array}{l}-0.019 * * * \\
(0.000)\end{array}$ \\
\hline Married & $\begin{array}{l}-0.029 * * * \\
(0.001)\end{array}$ & $\begin{array}{l}-0.026 * * * \\
(0.001)\end{array}$ & $\begin{array}{l}0.006 * * * \\
(0.001)\end{array}$ \\
\hline Widowed & $\begin{array}{l}0.001 * * * \\
(0.000)\end{array}$ & $\begin{array}{l}0.003 * * * \\
(0.000)\end{array}$ & $\begin{array}{l}0.032 * * * \\
(0.000)\end{array}$ \\
\hline Divorced & $\begin{array}{l}0.052 * * * \\
(0.000)\end{array}$ & $\begin{array}{l}0.053 * * * \\
(0.000)\end{array}$ & $\begin{array}{l}0.049 * * * \\
(0.000)\end{array}$ \\
\hline Pension & & & $\begin{array}{r}-0.000 \\
(0.000)\end{array}$ \\
\hline UI & & & $\begin{array}{l}0.007 * * * \\
(0.000)\end{array}$ \\
\hline Welfare & & & $\begin{array}{l}0.094 * * * \\
(0.000)\end{array}$ \\
\hline DI & & & $\begin{array}{l}0.167 * * * \\
(0.000)\end{array}$ \\
\hline Other social benefits & & & $\begin{array}{l}0.008 * * * \\
(0.001)\end{array}$ \\
\hline Constant & $\begin{array}{l}0.261 * * * \\
(0.004)\end{array}$ & $\begin{array}{l}0.235 * * * \\
(0.004)\end{array}$ & $\begin{array}{l}0.163 * * * \\
(0.002)\end{array}$ \\
\hline Age fixed effects & Yes & Yes & Yes \\
\hline Industry fixed effects & No & Yes & Yes \\
\hline Benefit controls & No & No & Yes \\
\hline Observations & $\begin{array}{r}6,811,939 \\
0.016\end{array}$ & $\begin{array}{r}6,811,939 \\
0.017\end{array}$ & $\begin{array}{r}6,811,939 \\
0.038\end{array}$ \\
\hline
\end{tabular}

Notes: The outcome is an indicator for whether the person was on anti-depressants in the next five years. Sample contains me women born between 1943 and 1954, observed from 2006 through 2011. For cohorts born between 1943 and 1945, observations after 2009 are not included. All models include controls indicator for DWB eligible cohorts, indicator for younger ineligible cohorts, income in 1999, year and age fixed effects. Robust standard errors clustered at the birth cohort - year level in parentheses. $* * * \mathrm{p}<0.01$.

Source: Authors’ calculations using non-public microdata from Statistics Netherlands, 2006-2016. 
Table A4a. Full 2SLS Estimates of Depression Risk on Working Status - Men, 2006-2011

\begin{tabular}{|c|c|c|c|}
\hline & $(1)$ & $(2)$ & (3) \\
\hline \multirow[t]{2}{*}{ Working } & 0.048 & 0.043 & 0.070 \\
\hline & $(0.030)$ & $(0.030)$ & $(0.049)$ \\
\hline \multirow[t]{2}{*}{ Married } & $0.007 * * *$ & $0.013^{* * *}$ & $0.005 *$ \\
\hline & $(0.002)$ & $(0.002)$ & $(0.003)$ \\
\hline \multirow[t]{2}{*}{ Widowed } & $0.023^{* * *}$ & $0.028 * * *$ & 0.008 \\
\hline & $(0.001)$ & $(0.001)$ & $(0.005)$ \\
\hline \multirow[t]{2}{*}{ Divorced } & $0.037^{* * *}$ & $0.040 * * *$ & $0.025 * * *$ \\
\hline & $(0.001)$ & $(0.001)$ & $(0.002)$ \\
\hline \multirow[t]{2}{*}{ Pension } & & & $0.028 * *$ \\
\hline & & & $(0.012)$ \\
\hline \multirow[t]{2}{*}{ UI } & & & $0.024 * * *$ \\
\hline & & & $(0.009)$ \\
\hline \multirow[t]{2}{*}{ Welfare } & & & $0.109 * * *$ \\
\hline & & & $(0.014)$ \\
\hline \multirow[t]{2}{*}{ DI } & & & $0.153 * * *$ \\
\hline & & & $(0.010)$ \\
\hline \multirow[t]{2}{*}{ Other social benefits } & & & 0.011 \\
\hline & & & $(0.007)$ \\
\hline Age fixed effects & Yes & Yes & Yes \\
\hline Industry fixed effects & No & Yes & Yes \\
\hline Benefit controls & No & No & Yes \\
\hline Observations & $6,953,084$ & $6,953,084$ & $6,953,084$ \\
\hline \multicolumn{4}{|l|}{ First stage } \\
\hline F statistic & 12 & 11 & 10 \\
\hline \multirow[t]{2}{*}{ DWB coefficient } & $0.034^{* * *}$ & $0.033 * * *$ & $0.022 * * *$ \\
\hline & $(0.009)$ & $(0.009)$ & $(0.006)$ \\
\hline
\end{tabular}

Notes: The outcome is an indicator for whether the person was on anti-depressants in the next five years. Sample contains men born between 1943 and 1954, observed from 2006 through 2011. For cohorts born between 1943 and 1945, observations after 2009 are not included. All models include controls for indicator for DWB eligible cohorts, indicator for younger ineligible cohorts, income in 1999, year and age fixed effects. The table reports the Kleibergen-Paap F statistic. Robust standard errors clustered at the birth cohort - year level in parentheses. *** $\mathrm{p}<0.01$.

Source: Authors’ calculations using non-public microdata from Statistics Netherlands, 2006-2016. 
Table A4a. Full 2SLS Estimates of Depression Risk on Working Status - Women, 2006-2011

\begin{tabular}{lccr}
\hline & $(1)$ & $(2)$ & \multicolumn{1}{c}{$(3)$} \\
\hline Working & 0.613 & 0.259 & 1.780 \\
Married & $(2.590)$ & $(0.716)$ & $(27.517)$ \\
& $-0.028^{* * *}$ & $-0.026^{* * *}$ & 0.108 \\
Widowed & $(0.003)$ & $(0.001)$ & $(1.563)$ \\
& 0.003 & $0.003^{* * *}$ & -0.091 \\
Divorced & $(0.007)$ & $(0.001)$ & $(1.894)$ \\
& 0.039 & $0.046^{* * *}$ & -0.004 \\
Pension & $(0.050)$ & $(0.015)$ & $(0.808)$ \\
& & & 0.311 \\
UI & & & $(4.756)$ \\
& & & 0.235 \\
Welfare & & & $(3.489)$ \\
& & & 0.343 \\
DI & & & $(3.795)$ \\
& & & 0.520 \\
Other social benefits & & & $(5.405)$ \\
& & & 0.212 \\
Age fixed effects & Yes & Yes & $(3.123)$ \\
Industry fixed effects & No & Yes & Yes \\
Benefit controls & No & No & Yes \\
\hline Observations & & & $6,811,939$ \\
\hline First stage & & & \\
$\quad$ F Statistic & & & $0.011,939$ \\
DWB coefficient & 0.001 & 0.003 & 0.000 \\
& $(0.004)$ & $(0.004)$ & $(0.004)$ \\
\hline
\end{tabular}

Notes: The outcome is an indicator for whether the person was on anti-depressants in the next five years. Sample contains women born between 1943 and 1954, observed from 2006 through 2011. For cohorts born between 1943 and 1945, observations after 2009 are not included. All models include controls for indicator for DWB eligible cohorts, indicator for younger ineligible cohorts, income in 1999, year and age fixed effects. The table reports the Kleibergen-Paap F statistic. Robust standard errors clustered at the birth cohort - year level in parentheses. $\mathrm{p}<0.01$.

Source: Authors’ calculations using non-public microdata from Statistics Netherlands, 2006-2016. 
Table A5a. Full OLS Estimates of Diabetes Risk on Working Status - Men, 2006-2011

\begin{tabular}{lccc}
\hline & $(1)$ & $(2)$ & $(3)$ \\
\hline Working & $-0.006^{* * *}$ & $-0.006^{* * *}$ & $-0.002^{* * *}$ \\
Married & $(0.001)$ & $(0.001)$ & $(0.000)$ \\
& $0.001^{* * *}$ & $0.002^{* * *}$ & $0.002^{* * *}$ \\
Widowed & $(0.000)$ & $(0.000)$ & $(0.000)$ \\
& $0.011^{* * *}$ & $0.011^{* * *}$ & $0.012^{* * *}$ \\
Divorced & $(0.001)$ & $(0.001)$ & $(0.001)$ \\
& $0.010^{* * *}$ & $0.010^{* * *}$ & $0.008^{* * *}$ \\
Pension & $(0.000)$ & $(0.000)$ & $(0.000)$ \\
& & & $-0.004^{* * *}$ \\
UI & & & $(0.000)$ \\
& & & $0.003^{* * *}$ \\
Welfare & & & $(0.000)$ \\
& & & $0.028^{* * *}$ \\
DI & & & $(0.001)$ \\
& & & $0.019^{* * *}$ \\
Other social benefits & & $0.001)$ \\
& & & $-0.001^{* * *}$ \\
Constant & & $0.049^{* * *}$ & $(0.000)$ \\
& & & $0.042^{* * *}$ \\
Age fixed effects & $\left(0.055^{* * *}\right.$ & Yes & $(0.001)$ \\
Industry fixed effects & Yes & Yos & Yes \\
Benefit controls & No & No & Yes \\
Observations & $6,281,092$ & $6,281,092$ & $6,281,092$ \\
& 0.007 & 0.008 & 0.009 \\
\hline
\end{tabular}

Notes: The outcome is an indicator for whether the person was on diabetes medication in the next five years. Sample contains men born between 1943 and 1954, who did not have any diabetes prescriptions at baseline, observed from 2006 through 2011. For cohorts born between 1943 and 1945, observations after 2009 are not included. All models include controls for indicator for DWB eligible cohorts, indicator for younger ineligible cohorts, income in 1999, year and age fixed effects. Robust standard errors clustered at the birth cohort - year level in parentheses. *** $\mathrm{p}<0.01$.

Source: Authors’ calculations using non-public microdata from Statistics Netherlands, 2006-2016. 


\begin{tabular}{lccc}
\hline & $(1)$ & $(2)$ & $(3)$ \\
\hline Working & $-0.007^{* * *}$ & $-0.006^{* * *}$ & $-0.003^{* * *}$ \\
Married & $(0.000)$ & $(0.000)$ & $(0.000)$ \\
& $-0.003^{* * *}$ & $-0.002^{* * *}$ & $0.002^{* * *}$ \\
Widowed & $(0.000)$ & $(0.000)$ & $(0.000)$ \\
& $0.006^{* * *}$ & $0.007^{* * *}$ & $0.012^{* * *}$ \\
Divorced & $(0.000)$ & $(0.000)$ & $(0.000)$ \\
& $0.005^{* * *}$ & $0.005^{* * *}$ & $0.003^{* * *}$ \\
Pension & $(0.000)$ & $(0.000)$ & $(0.000)$ \\
& & & $-0.001^{* * *}$ \\
UI & & & $0.000)$ \\
& & & 0.000 \\
Welfare & & & $0.000)$ \\
& & & $0.027^{* * *}$ \\
DI & & & $0.000)$ \\
& & & $0.013^{* * *}$ \\
Other social benefits & & $0.000)$ \\
Constant & & $0.042^{* * *}$ & $0.002^{* * *}$ \\
& & $(0.001)$ & $0.034^{* * *}$ \\
Age fixed effects & & Yes & $(0.001)$ \\
Industry fixed effects & Y.046** & Yes & Yes \\
Benefit controls & No & No & Yes \\
Observations & No & $6,312,257$ & $6,312,257$ \\
& $6,312,257$ & 0.007 & 0.008 \\
\hline
\end{tabular}

Notes: The outcome is an indicator for whether the person was on diabetes medication in the next five years. Sample contains women born between 1943 and 1954, who did not have any diabetes prescriptions at baseline, observed from 2006 through 2011. For cohorts born between 1943 and 1945, observations after 2009 are not included. All models include controls for indicator for DWB eligible cohorts, indicator for younger ineligible cohorts, income in 1999, year and age fixed effects. Robust standard errors clustered at the birth cohort - year level in parentheses. $* * * \mathrm{p}<0.01$.

Source: Authors’ calculations using non-public microdata from Statistics Netherlands, 2006-2016. 
Table A6a. Full 2SLS Estimates of Diabetes Risk on Working Status - Men, 2006-2011

\begin{tabular}{lccc}
\hline Dependent variable & $(1)$ & $(2)$ & $(3)$ \\
\hline Working & 0.013 & 0.014 & 0.015 \\
Married & $(0.014)$ & $(0.014)$ & $(0.022)$ \\
& 0.000 & 0.001 & 0.001 \\
Widowed & $(0.001)$ & $(0.001)$ & $(0.001)$ \\
& $0.010^{* * *}$ & $0.011^{* * *}$ & $0.010^{* * *}$ \\
Divorced & $(0.001)$ & $(0.001)$ & $(0.002)$ \\
& 0.010 & 0.010 & $0.007^{* * *}$ \\
Pension & 0.000 & 0.000 & $(0.001)$ \\
& & & 0.001 \\
UI & & & $(0.006)$ \\
& & & 0.006 \\
Welfare & & & $(0.004)$ \\
& & & $0.033^{* * *}$ \\
DI & & & $(0.006)$ \\
& & & $0.022^{* * *}$ \\
Other social benefits & & & $(0.004)$ \\
& & & 0.001 \\
Age fixed effects & & Yes & $(0.003)$ \\
Industry fixed effects & Yes & No & Yes \\
Benefit controls & No & & Yes \\
Observations & & & Yes \\
\hline First stage & & & $6,281,092$ \\
$\quad$ F Statistic & 10 & $(0.011)$ & 10 \\
DWB coefficient & $0.034^{* * *}$ & & $0.022^{* * *}$ \\
& $(0.011)$ & & $(0.007)$ \\
\hline
\end{tabular}

Notes: The outcome is an indicator for whether the person was on diabetes medication in the next five years. Sample contains men born between 1943 and 1954, who did not have any diabetes prescriptions at baseline, observed from 2006 through 2011. For cohorts born between 1943 and 1945, observations after 2009 are not included. All models include controls for indicator for DWB eligible cohorts, indicator for younger ineligible cohorts, income in 1999, year and age fixed effects. The table reports the Kleibergen-Paap F statistic. Robust standard errors clustered at the birth cohort - year level in parentheses. $*<0.01$;** $\mathrm{p}<0.05$; *** $\mathrm{p}<0.01$.

Source: Authors’ calculations using non-public microdata from Statistics Netherlands, 2006-2016. 
Table A6b. Full 2SLS Estimates of Diabetes Risk on Working Status - Women, 2006-2011

\begin{tabular}{|c|c|c|c|}
\hline Dependent variable & $(1)$ & (2) & (3) \\
\hline \multirow{2}{*}{ Working } & 0.642 & 0.410 & 1.546 \\
\hline & $(1.285)$ & $(0.530)$ & (7.508) \\
\hline \multirow[t]{2}{*}{ Married } & -0.002 & $-0.002 * *$ & 0.092 \\
\hline & $(0.003)$ & $(0.001)$ & $(0.433)$ \\
\hline \multirow[t]{2}{*}{ Widowed } & $0.008 * *$ & $0.007 * * *$ & -0.096 \\
\hline & $(0.004)$ & $(0.001)$ & $(0.521)$ \\
\hline \multirow[t]{2}{*}{ Divorced } & -0.008 & -0.004 & -0.042 \\
\hline & $(0.026)$ & $(0.012)$ & $(0.222)$ \\
\hline \multirow[t]{2}{*}{ Pension } & & & 0.269 \\
\hline & & & $(1.310)$ \\
\hline \multirow[t]{2}{*}{ UI } & & & 0.199 \\
\hline & & & $(0.966)$ \\
\hline \multirow[t]{2}{*}{ Welfare } & & & 0.245 \\
\hline & & & $(1.056)$ \\
\hline \multirow[t]{2}{*}{ DI } & & & 0.317 \\
\hline & & & $(1.474)$ \\
\hline \multirow[t]{2}{*}{ Other social benefits } & & & 0.179 \\
\hline & & & $(0.856)$ \\
\hline Age fixed effects & Yes & Yes & Yes \\
\hline Industry fixed effects & No & Yes & Yes \\
\hline Benefit controls & No & No & Yes \\
\hline Observations & $6,312,257$ & $6,312,257$ & $6,312,257$ \\
\hline \multicolumn{4}{|l|}{ First stage } \\
\hline F Statistic & 0 & 1 & 0 \\
\hline \multirow[t]{2}{*}{ DWB coefficient } & 0.002 & 0.004 & 0.001 \\
\hline & $(0.005)$ & $(0.005)$ & $(0.005)$ \\
\hline
\end{tabular}

Notes: The outcome is an indicator for whether the person was on diabetes medication in the next five years. Sample contains women born between 1943 and 1954, who did not have any diabetes prescriptions at baseline, observed from 2006 through 2011. For cohorts born between 1943 and 1945, observations after 2009 are not included. All models include controls for indicator for DWB eligible cohorts, indicator for younger ineligible cohorts, income in 1999, year and age fixed effects. The table reports the Kleibergen-Paap F statistic. Robust standard errors clustered at the birth cohort - year level in parentheses. ${ }^{*}<0.01 ; * * \mathrm{p}<0.05$; $* * * \mathrm{p}<0.01$.

Source: Authors' calculations using non-public microdata from Statistics Netherlands, 2006-2016. 


\section{RECENT WORKING PAPERS FROM THE CENTER FOR RETIREMENT RESEARCH AT BOSTON COLLEGE}

How Have Automation and Trade Affected the Taxable Share of Covered Earnings? Gal Wettstein, Matthew S. Rutledge, and Wenliang Hou, October 2018

Spillovers from State and Local Pensions to Social Security: Do Benefits for Uncovered Workers Meet Federal Standards?

Laura D. Quinby, Jean-Pierre Aubry, and Alicia H. Munnell, September 2018

Accounting for Social Security Claiming Behavior

Svetlana Pashchenko and Ponpoje Porapakkarm, September 2018

The Minimum Wage and Annual Earnings Inequality

Gary V. Engelhardt and Patrick J. Purcell, August 2018

Exploring the Consequences of Discrimination and Health for Retirement by Race and Ethnicity: Results from the Health and Retirement Study

Ernest Gonzales, Yeonjung Jane Lee, William V. Padula, and Lindsey Subin Jung, July 2018

Financial Management Support for SSA Beneficiaries: Looking Beyond the Payee Annie Harper, May 2018

What Factors Explain the Decline in Widows' Poverty?

Alicia H. Munnell, Geoffrey T. Sanzenbacher, and Alice Zulkarnain, May 2018

Exploring the Rise of Mortgage Borrowing among Older Americans

J. Michael Collins, Erik Hembre, and Carly Urban, May 2018

How Might Earnings Patterns and Interactions Among Certain Provisions in OASDI Solvency Packages Affect Financing and Distributional Goals?

Melissa M. Favreault, March 2018

Distributional Effects of Alternative Strategies for Financing Long-Term Services and Supports and Assisting Family Caregivers

Melissa M. Favreault and Richard W. Johnson, March 2018

How to Pay for Social Security's Missing Trust Fund?

Alicia H. Munnell, Wenliang Hou, and Geoffrey T. Sanzenbacher, December 2017

Retirement Prospects for the Millennials: What is the Early Prognosis?

Richard W. Johnson, Karen E. Smith, Damir Cosic, and Claire Xiaozhi Wang, November 2017

All working papers are available on the Center for Retirement Research website (http://crr.bc.edu) and can be requested by e-mail (crr@bc.edu) or phone (617-552-1762). 